\title{
Clover in agriculture: combined benefits for bees, environment, and farmer
}

\author{
Ciaran Harris $^{1}\left[\right.$ [ . Francis L. W. Ratnieks ${ }^{1}$
}

Received: 27 November 2020 / Accepted: 22 October 2021 / Published online: 10 November 2021

(c) The Author(s) 2021

\begin{abstract}
Concerns over the increasing cost and environmental impact of high inorganic nitrogen $(\mathrm{N})$ inputs have led to a reappraisal of the role of legumes, particularly clover, in maintaining soil fertility in improved grasslands. Clover and other legumes host the symbiotic root bacteria Rhizobium that fix $\mathrm{N}$, reducing the need for $\mathrm{N}$ fertiliser application. Grass plus clover swards are comparable to grass monocultures given medium to high inorganic $\mathrm{N}$ inputs in terms of companion grass growth, livestock performance and, yield of subsequently planted crops. Reduced $\mathrm{N}$ fertiliser input also reduces associated $\mathrm{N}$ leaching into water and greenhouse gas emissions during manufacture, transport, and application. In addition, increased use of clover in grasslands also benefit flower-visiting insects by providing an abundant source of nectar and pollen in summer. This is a critical period due to high levels of competition for these in summer. Because temporary and improved grassland covers almost half $(47 \%)$ of UK land area this habitat type has great potential in wildlife conservation. Further research is needed on the agronomic and conservation benefits of more diverse swards, as incorporation of additional forb species may complement clovers and legumes to benefit a wider range of flower-visiting insect species. In addition, more information on the attitudes of farmers for or against using clover and legumes in grasslands is needed, as they make the management decisions for most agricultural land in the UK. Implications for insect conservation: increased use of clover is a low-cost way to improve the food supply for flower-visiting insects, while to sustaining agricultural productivity and reducing environmental impact.
\end{abstract}

Keywords Pollinators · Clover · Grassland · Fertiliser

\section{Introduction}

Numerous legume species, Fabaceae, are grown for animal fodder via grazing, hay making and silage (Frame 2005; Watson and Stoddard 2017). Within Fabaceae, clovers play an important role in agriculture in Europe and elsewhere, with white (Trifolium repens) and red clover (T. pratense) the two most important legumes in UK farming (Frame 1987, 1990; Humphreys et al. 2017). Clover is often grown or sown with perennial ryegrass (Lolium perenne) in permanent or long-term pastures or in short-term grasslands known as leys grown in rotation with arable crops (Watson and Stoddard 2017). A primary agricultural benefit of clover is its ability to fix atmospheric nitrogen $(\mathrm{N})$ via symbiosis with

Ciaran Harris

ch442@sussex.ac.uk

1 Laboratory of Apiculture \& Social Insects (LASI), School of Life Sciences, University of Sussex, Falmer, Brighton BN1 9QG, UK root nodule bacteria, Rhizobium, contributing available $\mathrm{N}$ to grasslands (Hellriegel and Wilfarth 1888; Jørgensen et al. 1999; Ledgard et al. 2001; Høgh-Jensen et al. 2004; Hatch et al. 2007). This helps maintain soil fertility and increases yield, both of subsequent crops with leys (Høgh-Jensen and Schjoerring 1997) and companion grasses (Lüscher et al. 2008; Oberson et al. 2013). In addition, clover is itself an excellent animal feed with a higher $\mathrm{N}$ content than grass (Johnson and Thompson 1996; Fraser et al. 2004; reviewed in Peyraud et al. 2009) and can improve livestock performance via the superior nutritive value of grass plus clover forages versus grass alone (Wilkins et al. 1994; Johnson and Thompson 1996; Fraser et al. 2004). Clover and legumes are an important in organic farming when integrated with rotations, manure and crop residues, and leys (Watson et al. 2002).

Conservation and environmental concerns surrounding high $\mathrm{N}$ inputs in agriculture have led to increased discussion over the potential use of legumes in pastures and leys in conventional farmland systems as an alternative to grass 
monocultures and high inorganic $\mathrm{N}$ fertiliser applications (e.g. Frame 1987, 1990; Andrews et al. 2007; Chapman et al. 2017; DEFRA 2018; McKenna et al. 2018b). Intensive grassland management, which expanded and intensified throughout the twentieth century (Chamberlain et al. 2000), has been associated with environmental problems such as nitrate leaching into water courses (Jarvis 1993; Scholefield et al. 1993), greenhouse gas emissions from grasslands and during manufacture (Zhang et al. 2013; Liu et al. 2020), and reduced biodiversity (Firbank 2005; Maskell et al. 2010). Further, greater use of clover is increasingly beneficial economically because the cost of inorganic $\mathrm{N}$ has approximately doubled in real terms from the decade 1990-2000 to 2010 (Humphreys et al. 2017; DEFRA 2019; Fig. 1).

High artificial $\mathrm{N}$ inputs are an aspect of the wider process of agricultural intensification, which has been identified as a primary driver of insect decline (Ratcliffe 1984; Goulson et al. 2005, 2015; Carvell et al. 2006; Ollerton et al. 2014). Associated declines in floral resources in agricultural landscapes limit insect populations (Roulston and Goodell 2011; Goulson et al. 2015), and decreases in temporal continuity of pollen and nectar sources increases the risk of gaps in resource supply (Westphal et al. 2009; Couvillon et al. 2014a, b; Balfour et al. 2018; Timberlake 2019). Mitigating pollinator decline is of both environmental and economic importance as 35\% of global crop production (Klein et al. 2007 ) and $88 \%$ of flowering plant species (Ollerton et al. 2011) depend on animal pollination. Further, the economic value (2020 GBP) of insect pollination in the UK has been estimated at between $£ 364$ million (Carreck and Williams 1998) to £610 million (Smith et al. 2011). Preventing pollinator decline through effective strategies is, therefore, not only a concern for conservationists but also of direct economic importance for farmers. The potential effects of changes in agricultural practices on insects should be a consideration for changes in agricultural practices and policy.
The value of grassland habitats and clover in providing food for flower-visiting insects is well known. White and red clover are important sources of nectar and pollen for bumblebees in the UK (Goulson et al. 2005), New Zealand (Goulson and Hanley 2004), the United States (Rao and Stephen 2010), and Sweden (Rundlöf et al. 2014). Clover species are also important for providing honeybee forage (Decourtye et al. 2010) and white clover is a major nectar flow for beekeepers (Crane 1976). Improved grassland is considered to be the biggest contributor to the national nectar supply and within improved grasslands white clover is the most important nectar producing plant (Baude et al. 2016). Further, the decline of white clover in the twentieth century is suggested to be a contributing factor to national extinctions of bees and other aculeate Hymenoptera (Ollerton et al. 2014) and flower visiting insects over that period (Balfour et al. 2018; Carvell et al. 2006). Reductions of clover content of grasslands may have deleterious effects on insects by directly decreasing available floral resources, or indirectly by increasing competition for alternative resources (Balfour et al. 2015b; Wignall et al. 2020a). In 2020, only c. $38 \%$ of leys were sown with a clover mix (data from DEFRA 2020), indicating the potential for increased clover use. An increase in grass plus clover mixes may, therefore, benefit flower-visiting insects by helping to mitigate nectar and pollen deficits that have resulted from agricultural intensification, such as reductions in weeds in arable land and reductions in hay meadows (Goulson et al. 2005; Potts et al. 2010). Indeed, Baude et al. (2016) identified productive grassland as a habitat type with the greatest potential to improve the UK pollen and nectar supply.

This is particularly relevant to the UK as agricultural policy is currently being restructured, with the schemes available under the EU's Common Agricultural Policy being phased out over the next 7 years in England and Wales (DEFRA 2020b). The Sustainable Farming Incentive will
Fig. 1 Agricultural price index (API) of fertiliser in the UK. Fertiliser includes mineral and organic sources of nitrogen and phosphates. API assigns weights to goods or services which reflect their contribution to the annual agricultural accounts (Eurostat 2002). Data from DEFRA (2019)

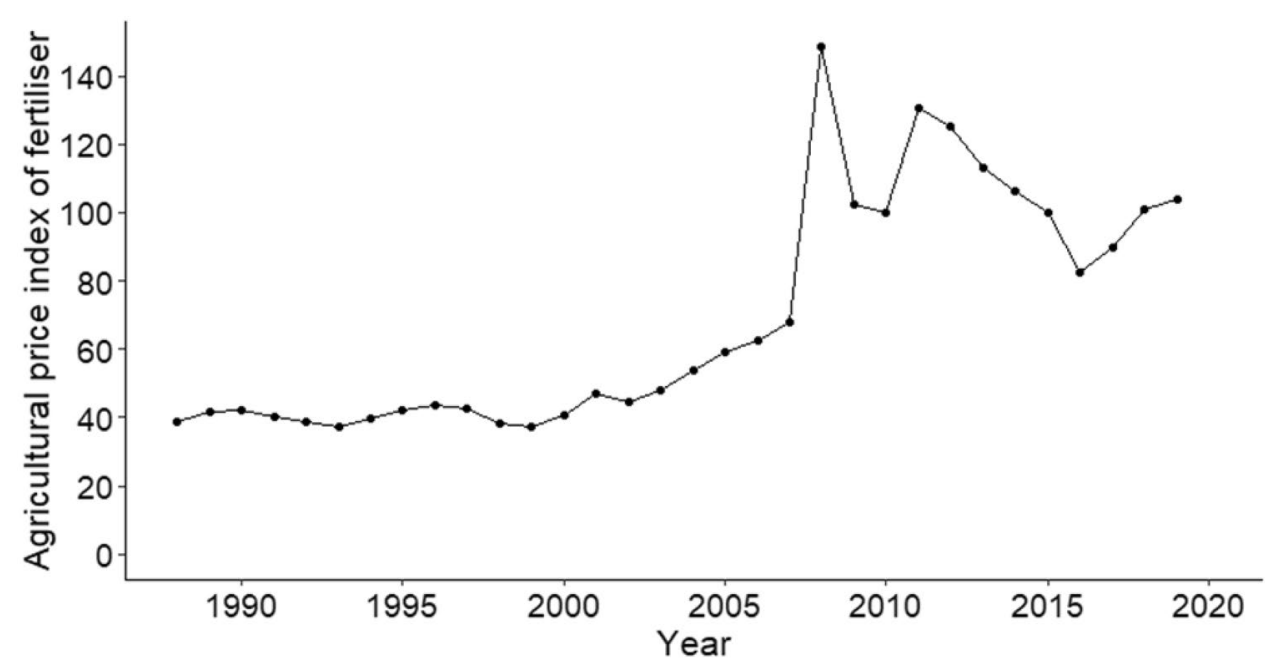


be one of three new payment schemes where payments will be based on environmental outcomes and public goods to encourage sustainable land management. One of the aims of the new scheme will be to incentivise land managers to deliver "thriving plants and wildlife" (DEFRA 2020b). Several 'standards' within the scheme are being developed which are targeted towards improved grassland, for example reducing inputs and increasing sward diversity (DEFRA 2021a, b). 2021 is the pilot year of the Sustainable Farming Incentive, with the scheme itself still under development and payment rates to still be decided. The full rollout of the scheme will occur between 2022 and 2024 .

Here we review the potential for the use of clover and legumes to be a component of the UK's strategy for meeting its commitments to improving biodiversity. Although there is extensive literature on the agronomic and environmental benefits of grass plus clover swards, the potential benefits to pollinating insects tend to be overlooked. This aspect of grass plus clover swards should be a key component of changes to policy and incentives, due to the prevalence of improved grassland (DEFRA 2019) and its high potential for improving floral resources for insects (Baude et al. 2016). Our aim in this article is to bridge this gap by summarizing both the current discussion surrounding the agronomic use of grass plus clover swards and their contribution to floral resources. We argue that the conjuncture of high fertiliser prices, environmental concerns associated with high $\mathrm{N}$ input, and restructuring of UK agricultural policy is a key opportunity to increase the use of clover in UK farming, providing environmental and economic benefits while simultaneously improving floral resources for flower visiting insects.

We chose relevant studies to give an overview of the agronomic and environmental benefits of clover, before arguing that flower-visiting insects should be an added consideration for grassland management and an added benefit of expanding clover use. This can be through direct benefits via resource provision, or indirect benefits through reducing resource competition of alternative food sources. We then further discuss how these benefits may be further maximised by incorporating additional plant species into grassland swards, expanding the potential groups of insects which may directly benefit. Finally, we relate these benefits to policy and the importance of grasslands within the farming matrix.

Due to the wide scope of this article, we are unable to provide an exhaustive analysis of all relevant work, and comprehensive reviews of agronomic and environmental aspects of clover use in agriculture are available elsewhere (e.g. use of white clover in dairy pastures, Andrews et al. 2007; use of legumes in grassland-livestock systems, Lüscher et al. 2014; red clover in cereal rotations McKenna et al. 2018b; agronomic and environmental benefits of leys, Martin et al. 2020). We use examples and knowledge from temperate regions outside of the UK, but we limit discussion of agricultural policy to the UK. This is to keep the scope and length of the article within reasonable limits, and because of the current debates over the future of UK agricultural policy. Although we specifically discuss the use of clover relates to the UK context, the information and insights in this article are, nevertheless, relevant to other countries. Our article is therefore relevant to the current situation in which the conservation and environmental dimensions of farming are increasingly wide ranging and important, while the challenges of farm economics and the human food supply remain, and in resulting policy recommendations, regulations and incentives.

\section{Historical perspective on the role of clover in agriculture}

Initially domesticated in southern Spain, clover spread through European farming and achieved wide distribution by the seventeenth century (Fussell 1964; Kjærgaard 2003). This allowed European agriculture to improve soil $\mathrm{N}$ content which had limited production (Kjærgaard 2003). The use of white clover in crop rotations and for fodder during this period contributed to increased harvests of subsequent crops during the English agricultural revolution (Kitsikopoulos 2004). Chorley (1981) estimated a $175 \%$ increase in production in European agriculture between 1750 and 1880 , a large proportion of which could be attributed to the doubling of nitrogen added to the soil through the use of clover (Kjærgaard 2003). Due to its use as fodder, clover also allowed more to be produced on less land, reducing the need to expand grazing areas into less suitable and forested areas (Kjærgaard 2003). European colonisation of North America, Australia and New Zealand also led to the expansion of clover, particularly white clover, to these non-native areas (Frame and Newbould 1986).

Increasing imports of guano, a natural nitrogen rich fertiliser, in the latter half of the nineteenth century followed by the development of the Haber-Bosch process for fixing atmospheric nitrogen into ammonia in the early twentieth century lead to increased reliance on inorganic $\mathrm{N}$ inputs to maintain productivity in farmland including grasslands (Mitchell 1988; Brassley 2000; Chamberlain et al. 2000; Kjærgaard 2003; Fig. 2). Intensification continued after the Second World War with a $40 \%$ and $58 \%$ reduction in white and red clover coverage respectively between 1978 and 2007 in the UK (data from 1978 to 2007 countryside survey; Barr et al. 2014a, b, c; Bunce et al. 2014, Fig. 3). Similar reductions in red clover have been recorded in Europe and New Zealand (Carvell et al. 2006; Goulson and Hanley 2004; Kleijn and Raemakers 2008).

Honey production increased dramatically during the eighteenth and nineteenth centuries due to the increased 
Fig. 2 Fertiliser application in United Kingdom between 1867 and 2019. Includes all chemicals or organic substances which improve soil fertility. Input quantified by total amount (£) spent on fertilisers adjusted to 2019 prices. Data from Mitchell (1988) and DEFRA (2019)
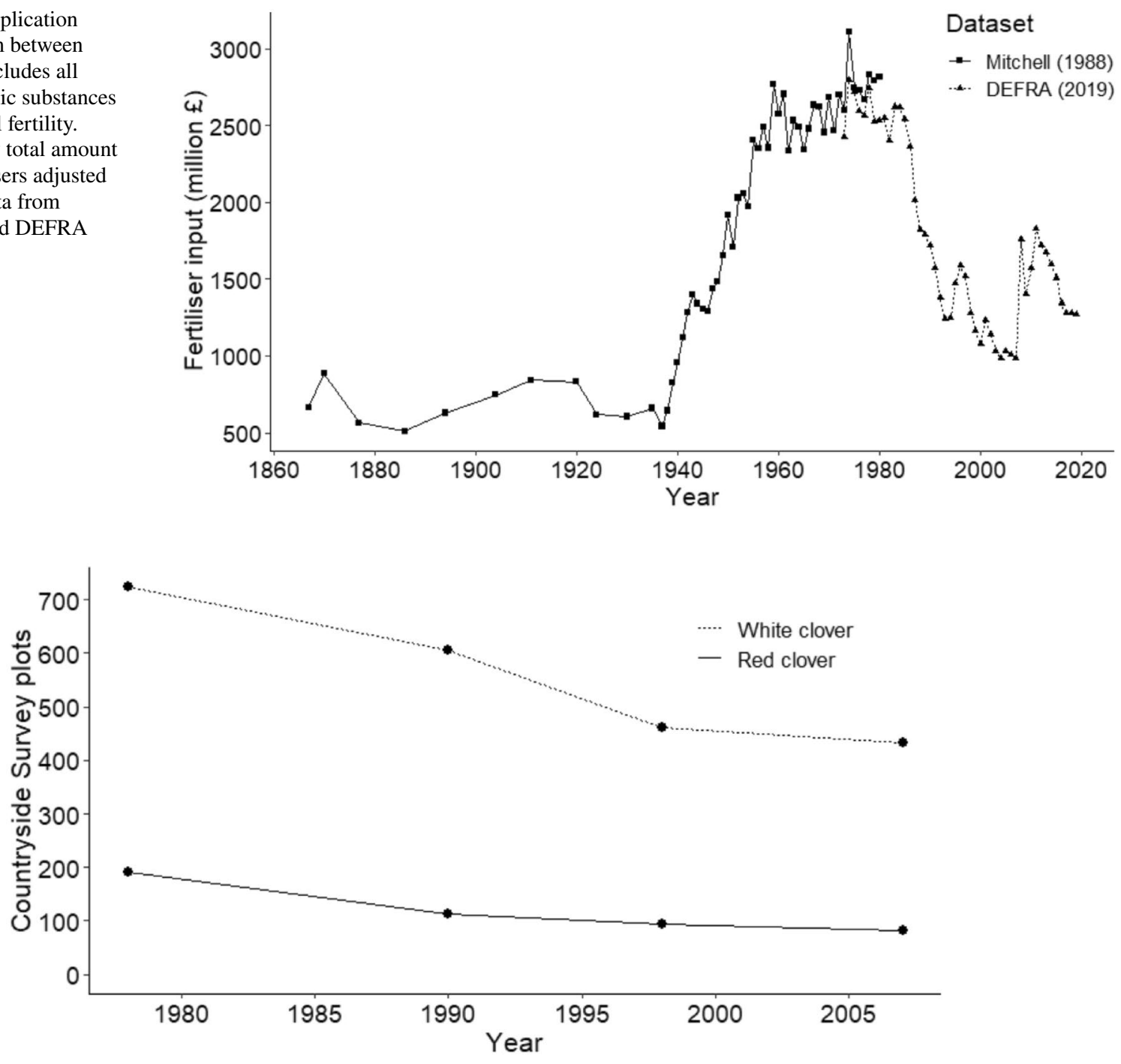

Fig. 3 Changes in the number of UK Countryside Survey plots where red and white clover were recorded between 1978 and 2007. 2591 $\mathrm{km}^{2}$ sampling squares were established across Britain. Within squares plots were established encompassing a range of habitats. Linear habitats and non-linear habitats had plot dimensions of $10 \mathrm{~m}^{2}$ and $200 \mathrm{~m}^{2}$ respectively. Presence (frequency) of all vascular plants was recorded

presence of clover in the European landscape (Kjærgaard 2003). In 1952 white clover was the primary nectar flow for beekeepers in the UK (Deans 1957). However, by 1993 it was considered less important than plants such as the crop oilseed rape (Brassica napus), the wildflower bramble (Rubus fruticosis), and flowering trees, primarily due to decline in white clover use in grassland (Carreck et al. 1997; Carreck and Little 1993).

Economic, ecological and environmental considerations are leading to a re-evaluation of high $\mathrm{N}$ fertiliser applications (e.g. Andrews et al. 2007; McKenna et al. 2018b). In 1991 the European Commission introduced the Directive on Nitrate which aimed to reduce water pollution caused or during surveys in 1978, 1990, 1998 and 2007 (Barr et al. 2014a, b, c; Bunce et al. 2014; Wood et al. 2017). Plots were filtered to only include those which were surveyed in all four years and the number of plots where white and red clover were recorded was quantified for each year

induced by nitrate from agriculture. The directive required member states to apply agricultural action programmes throughout their respective territories. As of 2021, over half, 55\%, of the UK is classified as nitrate vulnerable zones (NVZ, DEFRA 2021a). Within these areas there are limits to the amounts of both organic and inorganic nitrogen fertiliser which can be applied (Environmental Audit Committee 2018). A resulting decrease in productivity in these areas has led to suggestions that grass plus clover swards may be able to reconcile productivity with reduced environmental impact compared to grass monocultures with high inorganic $\mathrm{N}$ input (Andrews et al. 2007). In addition, the cost of artificial fertiliser has approximately doubled in real terms between 
the decade 1990-2000 and 2020 (Humphreys et al. 2017; Fig. 1.), making high artificial $\mathrm{N}$ applications even less economically viable. This has led to increasing interest in use of grass plus clover swards in the UK by policy-makers (DEFRA 2021a, b), researchers (Andrews et al. 2007), and farmers (DEFRA 2018). Outside of the UK, some countries, such as New Zealand and Australia, have long used white clover for N fixation in pastures (Brock et al. 1989; Peoples and Baldock 2001), whereas other countries in north-west Europe also have the potential to expand use of clover in grasslands due to EU Directive on Nitrate no longer permitting high rates of $\mathrm{N}$ applications (Humphreys et al. 2017).

\section{Agronomic benefits of grass plus clover swards}

Red and white clover are commonly used in grass plus legume mixes (Frankow-Lindberg 2017; Humphreys et al. 2017). Other Fabaceae are also used, including sainfoin (Onobrychis viciifolia Scop.), alfalfa (Medicago sativa), birdsfoot trefoil (Lotus corniculatus L.) and other Trifolium species such as crimson clover (T. incarnatum, AHDB 2018).

Differences in the persistence of white and red clover lead to differences in their use. Young shoots of red clover are above the ground surface and vulnerable to grazing damage (Black et al. 2009) so that growth and competitive ability are reduced due to crown damage by grazing via treading, selective grazing and increased $\mathrm{N}$ to grass from excreta (Black et al. 2009). Even with low stocking and rotational grazing red clover persistence is limited to 2-3 years, and increasing the number of annual defoliations from 3 to 6 decreases yield by $30 \%$ (Sheldrick et al. 1986). For this reason, red clover is mainly used to increase sward quality for cutting or short-term leys. By contrast, the superior persistence of white clover (up to 15 years) is well suited for grazing (Mela 2003; Black et al. 2009; Stoddard et al. 2009).

Grass plus clover mixtures achieve similar or greater productivity than high input grass monocultures due to differences in functional traits and complementarity of resource use. Grasses have fast growing and highly branched root systems, while clovers are less competitive for available nutrients due to their shorter and less branched roots (Haynes 1980). N contributions from clover and legume cultivation are derived from $\mathrm{N}$ transfer to companion species from Rhizobium fixation during the growth phase from living plant roots, decay and mineralisation of the legume upon termination, and grazing animal excreta after consumption (Wacquant et al. 1989; Ledgard 1991; Gregory 2006; Oberson et al. 2013).

Growth of perennial ryegrass in the UK is generally $\mathrm{N}$ limited (Andrews et al. 2007). Grass plus white clover swards are comparable to high input grass monocultures in terms of both herbage yield and livestock performance across a range of regions and management regimes (Chapman et al. 2017). White clover can fix between 150 and $280 \mathrm{~kg} \mathrm{~N} \mathrm{ha}^{-1}$ and is suited to both grazing and silage (AHDB 2018). In Switzerland, grass plus clover swards receiving $50-150 \mathrm{~kg} \mathrm{~N} \mathrm{ha}^{-1}$ year $^{-1}$ achieved dry matter yield comparable to that of grass monocultures with inputs of $450 \mathrm{~kg} \mathrm{~N} \mathrm{ha}^{-1}$ year $^{-1}$ (Nyfeler et al. 2009). A four-year field trial experiment across 21 sites in England and Wales consistently found that swards combining perennial ryegrass with white clover gave dry matter and milk yield equivalent to perennial ryegrass monocultures fertilised with an additional $200 \mathrm{~kg} \mathrm{~N} \mathrm{ha}^{-1}$ year $^{-1}$ or $70 \%$ or more of the yield of grass monocultures with a high input of $400 \mathrm{~kg} \mathrm{ha}^{-1}$ year $^{-1}$, given correct management (Doyle et al. 1984; reviewed in Andrews et al. 2007). A pan European analysis of 28 countries found that well-balanced grass plus legume swards grown at low $\mathrm{N}$ input levels achieved above ground biomass comparable to high $\mathrm{N}$ input grass monocultures (Lüscher et al. 2008). Organic matter digestibility and herbage intake by grazing livestock increases with sward white clover content (Thomson et al. 1985; Wilkins et al. 1994). The nutritional quality of white clover also declines at a lower rate than grass with ageing (reviewed in Peyraud et al., 2009).

Red clover also has a dual role as a fodder crop and in soil fertility building, being able to fix between 200 and $300 \mathrm{~kg} \mathrm{~N} \mathrm{ha}^{-1}$ year $^{-1}$ (AHDB 2018). Its ability to rapidly build up soil fertility within one year has led to a reappraisal of its potential in arable rotations (e.g. Doel 2013; McKenna et al. 2018a). Trials in the UK have shown that grass plus red clover swards utilise available nutrients more efficiently than grass monocultures, contributing to increased yield of subsequently planted cereals (Doel 2013). Grass plus red clover swards have also been found to increase production of above ground biomass, dry matter yield, and digestible organic matter compared to grass monocultures (de Haas et al. 2019; Barneze et al. 2020). However, despite improving dry matter yield when grown in a grass mixture compared with grass monocultures (de Haas et al. 2019; Barneze et al. 2020), red clover is not as well suited to grazing as white clover due to lower production potential in grazed swards and is, therefore, grown more for silage for winter feeding of ruminants (Frankow-Lindberg 2017). Red clover is also more vulnerable to diseases than white clover, and rotations with breaks of up to eight years between red clover plantings are sometimes required for control of soil-borne diseases, fungi and pests (AHDB 2018).

In a multi-site grassland experiment across 32 European countries, benefits associated with grass plus red clover and grass plus white clover swards were consistent across a range of climatic conditions, three experimental years and over a range of $\mathrm{N}$ input levels (Nyfeler et al. 2011). Red or white 
clover plus grass swards increased both the $\mathrm{N}$ gained through fixation by symbiotic bacteria and improved the uptake efficiency of non-symbiotic N. The greatest benefit of grass plus clover swards was at low to moderate inorganic $\mathrm{N}$ input levels (50 kg ha $\mathrm{kg}^{-1}$ and $150 \mathrm{~kg} \mathrm{ha}^{-1}$ respectively), due to upregulation of symbiotic $\mathrm{N}$ fixation by the legumes at lower $\mathrm{N}$ input levels to close the gap between non-symbiotically fixed $\mathrm{N}$ availability and $\mathrm{N}$ demand for plant growth (Nyfeler et al. 2011).

Mixtures of perennial ryegrass and red clover also improve soil structure and increase the abundance of top-soil dwelling earthworms, which facilitate better root development and deeper penetration (de Haas et al. 2019). Further, the complementarity between functional traits in grass plus clover swards reduce the invasion of weeds due to better utilisation of available resources (Lüscher et al. 2008; de Haas et al. 2019). White clover is not drought tolerant, and the timing of drought in relation to the life cycle stage of white clover can be a primary factor in recovery and persistence (Knowles et al. 2003).

Perennial ryegrass plus white or red clover can also bring short-term benefits when used as cover crops or green manure (Tonitto et al. 2006; Stinner et al. 2008; Brozyna et al. 2013; Doel 2013). White and red clover green manures achieved significantly higher subsequent winter wheat yield, dry matter yield and $\mathrm{N}$ content after 1 year of green manuring than birds foot trefoil green manure and perennial ryegrass monocultures in UK field trials (Stopes et al. 1996). Both red and white clover also increase spring wheat yields after their short-term inclusion in cereal rotations and when undersown (Doel 2013). However, for short-term fertility building red clover is superior to white clover in terms of yield and weed suppression (Stopes et al. 1996; KoehlerCole et al. 2016).

The white clover content of swards is improved under rotational than continuous grazing due to intervals between defoliation allowing redevelopment of leaf area (Curll and Wilkins 1983). However, insufficient grazing or cutting can also reduce white clover as companion grasses outcompete white clover and inhibit growth (Steen and Laidlaw 1995). Therefore, management of white clover plus grass swards should aim for a level of grazing intensity between these two extremes. The choice of cultivar is an important factor in striking this balance. Small-leaved white clover cultivars are best suited to sheep grazing, medium-leaved to rotational grazing and large-leaved to cattle grazing (Black et al. 2009). Broadcasting or strip seeding can further increase the proportion of white clover in pastures (Frame and Newbould 1986; Frame 1987). The most common frequency for reseeding white clover in temporary grassland in the UK is 3-5 years (DEFRA 2020a).

Artificial $\mathrm{N}$ application to grass plus clover swards decreases clover content. Artificial $\mathrm{N}$ applications can further increase ryegrass competitive ability and reduce clover persistence (Armstrong et al. 1999). Furthermore, white clover is less competitive at gaining nutrients and it is sometimes necessary to apply $\mathrm{P}$ or $\mathrm{K}$ to maintain clover at sufficient levels (Evans 1977; Frame and Newbould 1986; FAS 2019). Clover is less tolerant of low soil pH levels than ryegrass, and applications of lime may be necessary to increase soil pH (FAS 2019). Regular soil analysis is needed to maintain clover content at good levels and maximise yield and profitability (FAS 2019).

\section{Environmental benefits of grass plus clover swards}

Leys and pastures can have substantial $\mathrm{N}$ surpluses primarily from livestock urine patches (Monaghan et al. 2007), but also from soil organic matter, and occasional high inputs via manure, slurry, or commercial fertiliser (Ryden et al. 1984; Addiscott 1996; Eriksen 2001). As the ability of soils to conserve excess $\mathrm{N}$ is limited, $\mathrm{N}$ can be leached as nitrate $\left(\mathrm{NO}_{3}{ }^{-}\right)$into groundwater, runoff into surface drainage and ultimately rivers and lakes, or emitted as gaseous nitrous oxide $\left(\mathrm{N}_{2} \mathrm{O}\right)$, ammonia $\left(\mathrm{NH}_{3}\right)$, nitric oxide $(\mathrm{NO})$, and dinitrogen $\left(\mathrm{N}_{2}\right)$ (Jarvis 1993; Luo et al. 2010). This can contribute to eutrophication, water contamination, biodiversity loss and greenhouse gas production (IPCC 2006; Jarvis 1993; Maskell et al. 2010; Wedin and Tilman 1996). The cost of fertiliser loss in lowland UK farming has been estimated to be $£ 10,000-£ 20,000$ per $\mathrm{km}^{2}$ and equipment needed for the treatment of high nitrate levels in water is a significant cost for water companies (Environmental Audit Committee 2018).

Leaching associated with animal urine patches, which accounts for an estimated $70-80 \%$ of total $\mathrm{N}$ leaching (Monaghan et al. 2007), is likely to be similar for ryegrass monocultures and grass plus clover swards (Ledgard et al. 2009). However, $\mathrm{N}$ leaching is higher for grass monocultures due to fertiliser-specific losses (Ryden 1983; Ledgard et al. 2009). High artificial N inputs are both inefficient and environmentally damaging in this respect, as less than $20 \%$ of $\mathrm{N}$ input is incorporated into agricultural outputs (Jarvis 1993). Because legumes reduce the need for repeated applications of $\mathrm{N}$ fertiliser, they may reduce both the environmental and economic costs of grassland management (Andrews et al. 2007; Lüscher et al. 2014). Although significant nitrate leaching may still occur in grasslands incorporating legumes with low artificial N input (Scholefield and Oenema 1997; Rochon et al. 2004), leaching is minimised when soil and crop management is tailored to the specific rotation (Berntsen et al. 2006). Optimum systems should capture the benefits of $\mathrm{N}$ fixation by clover and legumes while reducing $\mathrm{N}$ fertiliser input, reducing the fertiliser-specific $\mathrm{N}$ losses 
associated with high fertiliser input required for grass monocultures (Clark and Harris 1995).

Being greenhouse gas neutral, symbiotic $\mathrm{N}$ fixation by legumes represents an opportunity to reduce greenhouse gas (GHG) production by reducing use of artificial fertilisers. This can be achieved through reducing direct GHG emissions, which occur directly through activities such as cultivation and harvesting, and indirect GHG emissions, through reducing emissions associated with production and transportation of artificial fertiliser (Wood and Cowie 2004). In terms of direct GHG emissions, the use of legumes in grasslands can reduce the emission of $\mathrm{N}_{2} \mathrm{O}$, a potent greenhouse gas, as $\mathrm{N}$ is not present in a reactive form in the soil and is instead fixed readily in root nodules (Lüscher et al. 2014). $10 \mathrm{~kg}$ of $\mathrm{N}_{2} \mathrm{O}$ is emitted from grasslands for every $100 \mathrm{~kg}$ of inorganic $\mathrm{N}$ fertiliser applied (IPCC 2006). Although reductions in $\mathrm{N}_{2} \mathrm{O}$ are not always detected in grass plus clover systems, such variability may be due to differences in experimental methods such as duration of the study (Barneze et al. 2020).

Clover and other legumes also represent an opportunity to reduce GHGs emitted in the production, transportation, and application of industrial $\mathrm{N}$ fertilisers. During manufacture 2.1-3.6 metric tonnes of $\mathrm{CO}_{2}$-equivalents (global warming potential over 100 years, IPCC 2014) are produced for every metric tonne of ammonia (Zhang et al. 2013; Liu et al. 2020), and worldwide ammonia production generates 420 million tonnes of $\mathrm{CO}_{2}$ per annum (Giddey et al. 2017). Overall, $\mathrm{N}$ fertiliser production accounts for approximately $1 \%$ of global GHG emissions, via $\mathrm{CO}_{2}, \mathrm{~N}_{2} \mathrm{O}$ and methane, $\mathrm{CH}_{4}$ (Wood and Cowie 2004). The primary greenhouse gases during production are $\mathrm{CO}_{2}$ during combustion of fossil fuels for ammonia synthesis and $\mathrm{N}_{2} \mathrm{O}$ from nitric acid production. $\mathrm{CO}_{2}$ production during transportation is also a major contributor for all fertiliser types and the primary source of GHG emission for phosphate fertilisers (Wood and Cowie 2004). In contrast, the energy required for symbiotic $\mathrm{N}$ fixation in legumes is from photosynthesis (Ledgard et al. 2009).

\section{An added benefit to clover use: helping flower visiting insects}

Recent interest in increasing the use of grass plus clover mixes and other legumes in grasslands is a potential low or zero-cost opportunity to increase pollen and nectar availability in addition to the ecological and economic benefits discussed above. Greater recognition of this potential benefit to pollinators may add further impetus to increased use of grass plus clover swards or leys. Agricultural land is 70-75\% of UK land area, and grassland is the single most important agricultural land use, accounting for a massive c. $47 \%$ of the UK land area (DEFRA 2019, Fig. 4). Grassland is by far the largest land type in the UK (Fig. 4), greatly exceeding arable crops (c.19\%) and woodlands (c.4\%). Permanent and temporary grassland have been and continue to be major components of the British agricultural landscape (Fig. 5a, b). However, as little as 1-2\% of permanent grassland in England and Wales is considered habitat rich in plant species, such as hay meadows and semi-natural grassland (Blackstock et al. 1999). Improved grassland has been highlighted as a particularly suitable habitat to increase resource provision for bees and other flower visiting insects at low cost. By assessing the floral records of different habitats across the UK over the
Fig. 4 Agricultural land use types in the UK and their proportion of total UK land area. Data from DEFRA (2019)

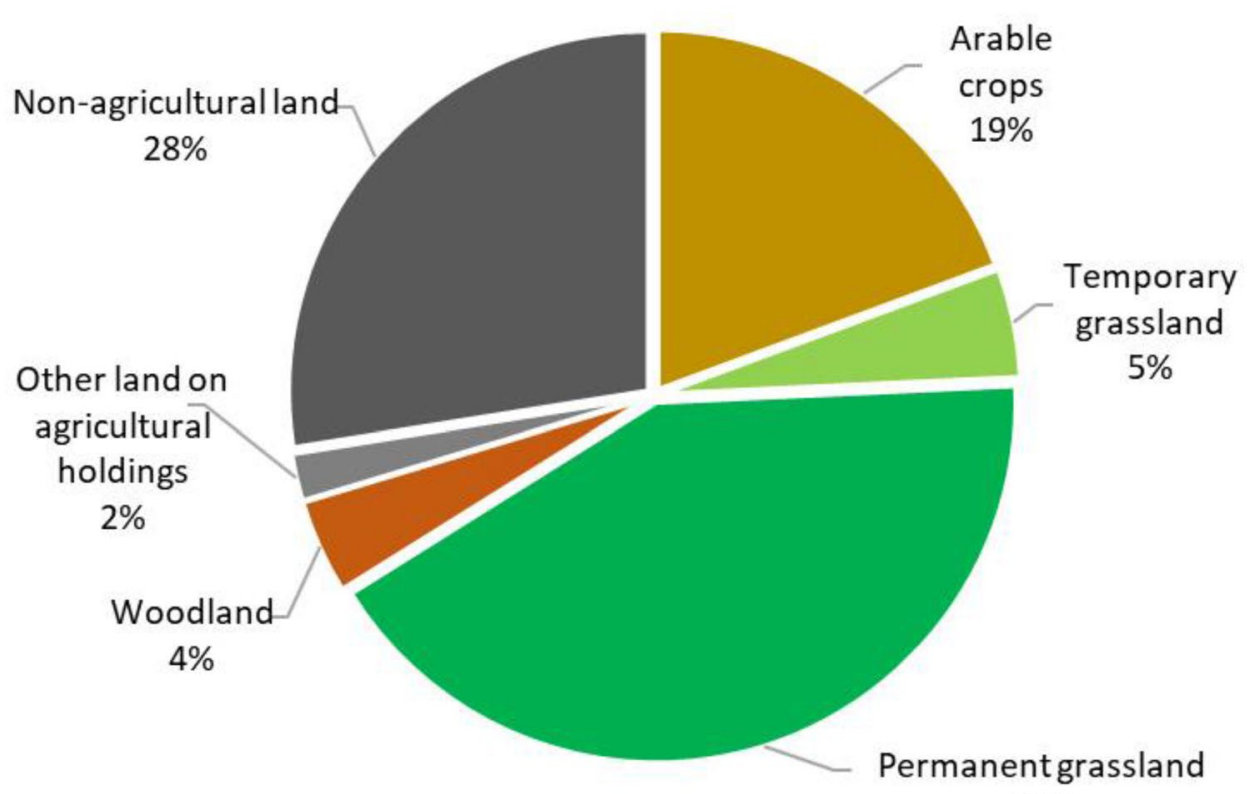

$42 \%$ 
Fig. 5 Changes in total area of permanent and temporary grassland in a) Great Britain between 1867 and 1980 (Mitchell 1988) and b) the UK between 1984 and 2019 (DEFRA 2019). Left axis is total hectares and right axis is percentage of land area used for permanent or temporary grassland
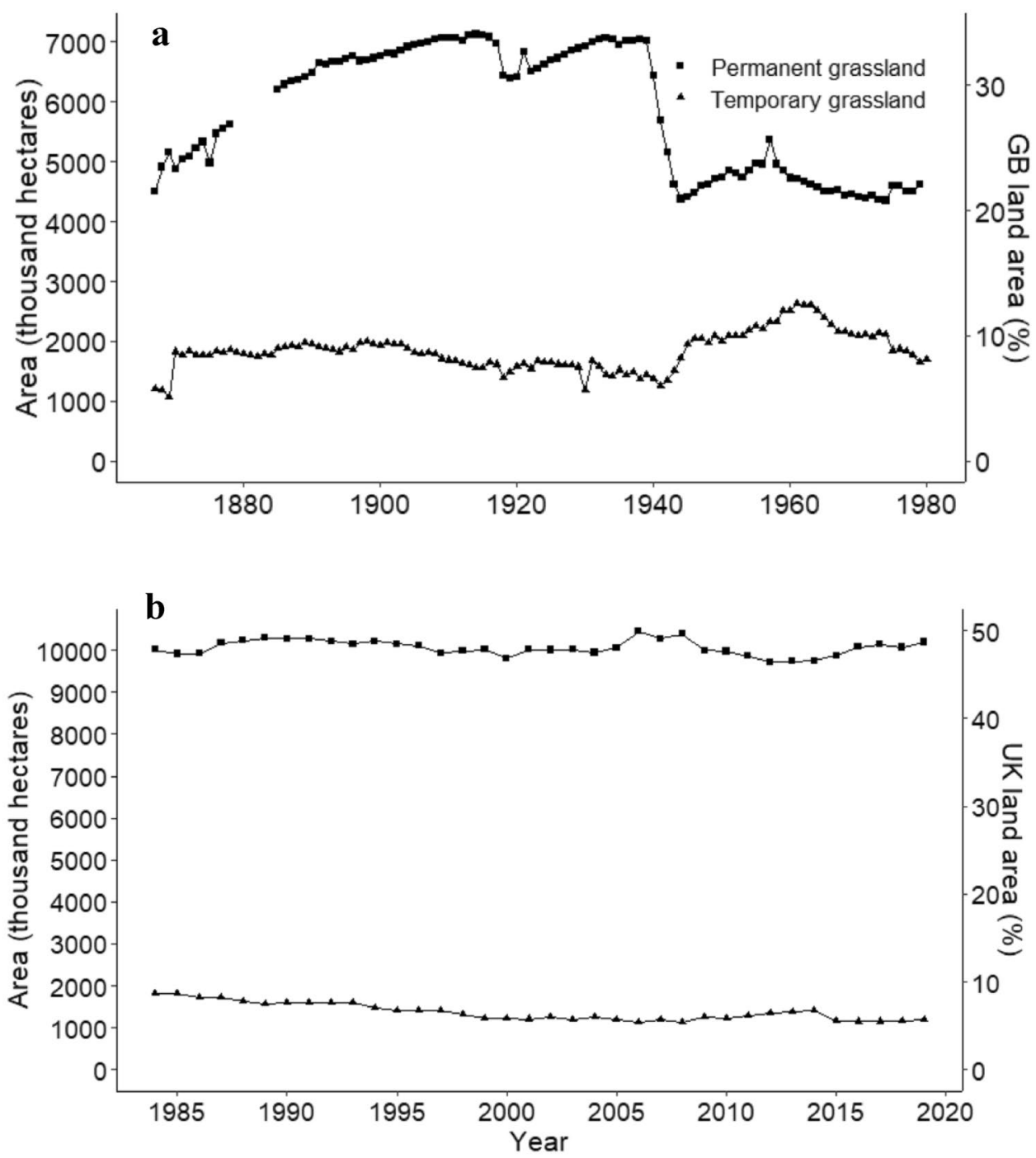

past century Baude et al. (2016) found improved grassland to be the greatest contributor to nectar in the UK due to its large area. Improved grassland has the potential to provide additional nectar through simple and low-cost measures, such as by adjusting management practices to grow more white clover and by allowing it to flower (Baude et al. 2016). White and red clover also produce pollen high in protein and amino acids (Hanley et al. 2008).

Importantly, reducing artificial $\mathrm{N}$ input in conventional grassland management and improving constituent floral resources does not require land to be taken out of production, unlike measures which aim to restore seminatural habitats or set aside sections of arable land such as with "buffer strips". This makes such strategies more cost-effective, less labour intensive and more economically viable than more ambitious conservation measures such as the reestablishment of diverse habitats (Littlewood et al. 2012). This may be a productive strategy as changes that interfere less with ongoing and day-to-day farming practices are favoured by European farmers (Bailey et al. 2015). Further, certain elements of organic farming which increase abundance and diversity of pollinators, such as the use of grass plus legume swards, can also be implemented in conventional management (Power and Stout 2011; DEFRA 2018). Helping pollinators in this way will result in no loss of production due to the high performance of grass plus clover swards. Some plant species identified as important for floral resource provision in grasslands, such as dandelion Taraxacum sp. and thistle Cirsium arvense, have little agronomic value and are generally considered to be weeds (Orford et al. 2016). Indeed, landholders are legally required to remove C. arvense in the UK (Weeds Act 1959). This contrasts with clover, which has considerable agronomic value in addition to being frequently visited by insects (Carvell et al. 2006; Decourtye et al. 2010; Goulson et al. 2005). The use of grass plus clover swards can, therefore, be a nocost or even win-win strategy by sustaining or improving 
agricultural production while reducing environmental impact and helping flower-visiting insects.

Analysis of floral and flower-visiting insect records has demonstrated the benefits derived from clover use by pollinators and the negative consequences of reduction. Decreased abundance and diversity of nectar production between 1978 and 1990 has been partly attributed to increased fertiliser application in agricultural land (Baude et al. 2016). Ollerton et al. (2014) reported that an acceleration in the rate of UK extinctions of bees and other aculeate Hymenoptera in the second half of the nineteenth century was likely attributable, in part, to an increased use of imported guano and a reduced reliance on strict rotational cropping, which would have utilised clover and other legumes. A further cluster of extinctions during the early twentieth century coincided with the development of the Haber-Bosch process and widespread introduction of nitrogen fertiliser causing declines of wildflowers (Wedin and Tilman 1996; Ollerton et al. 2014). Further, the disproportionate extinction of late summer-flying insects in the UK has been suggested to be due to the loss of late summer blooming plants (Balfour et al. 2018), of which white and red clover cover have declined by $40 \%$ and $58 \%$ respectively between 1978 and 2007 (from 1978-2007 countryside survey; Barr et al. 2014a, b, c; Bunce et al. 2014).

\section{Which bees and insects will benefit from increased clover?}

Honeybees are frequently recorded visiting white clover (Power and Stout 2011). An increased abundance of white clover in grasslands may help counteract the decline in managed honeybee colonies in the UK and North America, which have seen $75 \%$ and $62 \%$ declines in the past century respectively (Neumann and Carreck 2010; Levy 2011). This is of both ecological and economic importance due to increasing demand for pollination services (Aizen et al. 2008; Ellis et al. 2010; Neumann and Carreck 2010), and the importance of white clover for honey production (Crane 1976). Poor foraging conditions and starvation are frequently cited causes of colony loss by beekeepers (Otis 2007; Van Engelsdorp et al. 2007), and nutritional stress may exacerbate other stressors such as pathogens and pesticides (Naug 2009; Becher et al. 2013; Horn et al. 2019). In Western Europe red and white clover bloom between July and September and June and September respectively (Decourtye et al. 2010), and increases in the proportion of clover in grass plus clover swards occurs in mid to late summer (de Haas et al. 2019). This may coincide with critical periods in the honeybee colony cycle. Modelling and empirical work have demonstrated that late summer (July-August) forage gaps had the greatest influence on colony survival (Requier et al. 2017; Horn et al. 2019). Further, waggle dance decoding has indicated increased honeybee foraging distances in July and
August in agricultural landscapes, indicating reduced food availability (Couvillon et al. 2014b). This temporal instability of floral resource availability occurs in a critical period of honeybee colony cycle, in which colonies are reaching maximum brood rearing and adult population size and are storing honey for winter survival and for harvest by beekeepers. This in turn has cascading effects on life stages and tasks, negatively affecting colony viability (Horn et al. 2019).

In addition to honeybees, Fabaceae rich grasslands are important food sources for bumblebees (Goulson et al. 2005). Continuity of forage resources are important for bumblebees, as their annual colonies develop over a period of several months, typically from spring to summer. The timing of production of bumblebee sexuals varies depending on species, from May to early autumn (Hardman 2016). A successful colony life cycle requires a near-continuous supply of nectar and pollen from early spring to mid to late summer (Alford 1975; Westphal et al. 2009). Late summer is likely to be a challenging period for bumblebee colonies, due to a disproportionate decline in late summer flowering plant species in response to agricultural intensification and with the majority of flowering trees and mass-flowering crops, such as oilseed rape, Brassica napus, blooming in spring and early summer (Hardman 2016; Balfour et al. 2018).

Increased abundance of late-summer flowering species may, therefore, assist in counteracting these late season forage gaps as white clover can be the source of a high proportion of nectar during its flowering period (Timberlake et al. 2019). Floral resource production arising from clover plus grass mixtures coincides with periods of the summer which are more likely to have temporal gaps in floral nectar supply (Timberlake et al. 2019; Westphal et al. 2009) when bumblebee colonies have high nectar and pollen demand (Timberlake 2019). Timberlake et al. (2019) estimated that $1 \mathrm{~km}^{2}$ of farmland would require between 500 and 2000 extra grams of sugar per day to mitigate the July-August forage gap, which equates approximately to one hectare, $1 \%$ of the total area, of red clover. Landscapes containing monocultures of red clover were found to increase the production of bumblebee sexuals in Sweden (Rundlöf et al. 2014). Foraging queen abundance was $71 \%$ higher in uncultivated field margins in landscapes which contained red clover monocultures, even though these were a tiny fraction, less than $0.2 \%$, of the total area (Rundlöf et al. 2014).

Even within narrow pollinator guilds there can be large variation in the diet and foraging pattern of different species. For bumblebees, variation between forage plant species is affected by tongue length (Ranta and Lundberg 1980). White clover has been found to be dominated by shortertongued species of bumblebee (Fussell and Corbet 1991; Power and Stout 2011; Nichols et al. 2019), whereas red clover has been found to make up a greater proportion of the diets of longer tongued species, which also tend to be of 
greater conservation concern in the UK (Carvell et al. 2006; 2007; Fussell 1992). Indeed, agri-environment schemes aiming to create Fabaceae rich habitats have been suggested to benefit Fabaceae specialists such as B. lapidarius but not medium- to long-tongued species such as $B$. sylvarum, B. humilis, B. muscorum, B. ruderarius and B. ruderatus (Wood et al. 2015). An expansion of simple grass plus clover swards in the agricultural landscape may therefore disproportionately benefit certain pollinators over others, both within and between pollinator guilds. This has been demonstrated for some mass flowering crops such as oilseed rape, the increased cultivation of which has led to concerns over disproportionate benefits of shorter tongued bumblebee species at the expense of long-tongued species (Diekötter et al. 2010). Alternatively, mass flowering of clover may induce a 'magnet effect', reducing abundance of honeybees and bumblebees in adjacent habitats and on alternative floral resources (Montero-Castaño et al. 2016; González-Varo and Vilà 2017). This may indirectly benefit other insect groups by reducing inter-specific competition for other flower species in bloom nearby (Wojcik et al. 2018).

What about other flower-visiting insects? Although clover can be an important source of food for honeybees and bumblebees during summer, Fabaceae may be less favourable to the c.240 other bee species in the UK (Nichols et al. 2019; Wood et al. 2017). Although solitary bees are recorded foraging in clover-rich grasslands (Malone et al. 2010; Larson et al. 2014) and bee diversity can be improved with increases in the flower head density of Fabaceae in grasslands (Woodcock et al. 2014), solitary bees are less frequent visitors to Fabaceae (Nichols et al. 2019). Apiaceae and Asteraceae are probably more beneficial to a wider range of solitary bee genera (Nichols et al. 2019). Clover species and other Fabaceae species produce flowers with long corolla tubes which are also inaccessible to the mouthparts of many hoverfly species (Gilbert 1981; Branquart and Hemptinne 2000) which are important due to their abundance (Garbuzov and Ratnieks 2014) and are important part of the biodiversity of flower visiting insects. Considering the needs of these groups is of importance, both due to their contribution to pollination services (Ollerton et al. 2011; Jauker et al. 2012) and to overall species diversity and conservation.

\section{Further improving floral diversity of improved grasslands}

Policies which aim to incentivise farmers to implement more sustainable grassland management through use of clover also represents an opportunity to further improve floral diversity beyond simple grass plus clover swards. Floral resource diversity and abundance are known to affect bee community structure (Balfour et al. 2015a, b; Potts et al. 2003), and florally diverse improved grasslands benefit pollinator communities. In a four-year experiment in productive grasslands, Woodcock et al. (2014) found that the inclusion of a forb component in seed mixes increased the stability of pollinator abundance and diversity over the experimental period, including solitary bees, butterflies and hoverflies. The inclusion of forbs also increased flower density over the four years, which was positively correlated with pollinator species richness. Brown et al. (2012) examined the pollinator community of grasslands sown with diverse and non-diverse legume mixtures and found more diverse legume leys supported a greater diversity of pollinators, including hoverflies and solitary bee species. Furthermore, the increased floral diversity caused by the addition of legume and forb species in grassland swards increased the functional diversity of pollinator communities (Orford et al. 2016). In addition to supporting more diverse communities of pollinators, diverse grassland swards are better able to buffer against fluctuations in floral resource availability by providing a continuous succession of flowers (Brown et al. 2012; Doring et al. 2012), which is essential for bumblebee survival due their need for a near-continuous supply of floral resources (Westphal et al. 2009).

As discussed above, an expansion of simple grass plus clover swards may mainly benefit only some bee and flowervisiting insect species. Indeed, between 1978 and 2007 nectar diversity decreased significantly at the level of plant species and functional groups in arable land and improved grasslands (Baude et al. 2016). Nectar provision on farmland also tends to be dominated by a small number of plant species (Timberlake et al. 2019). Policies that reduce inorganic fertiliser input by utilising the nitrogen fixing potential of legumes could provide an additional benefit by increasing the floral diversity of improved grassland, taking into consideration the differing needs of a wide range of flowervisiting insect species and functional groups.

Legume species in multi-species mixes which provide both agronomic benefits and floral resources for insects include sainfoin (Onobrychis viciifolia Scop), vetches (Vicia spp.), and birdsfoot trefoil, (Lotus corniculatus, Brown, 2012; Vibart et al., 2016; AHDB, 2018). The non-legume forb component of diverse mixtures can include chicory (Cichorium intybus), yarrow (Achillea millefolium), black knapweed (Centaurea nigra), and ox-eye daisy (Leucanthemum vulgare, Woodcock et al., 2014), which are Asteraceae. It may be also desirable to include species from a broader range of families beneficial to wild bees such as Apiaceae and Geraniaceae (Nichols et al. 2019).

\section{Agronomic benefits of diverse swards}

Plant species biodiversity in grasslands can increase primary productivity through niche complementarity and more 
efficient utilisation of available resources (Tilman et al. 1996; Hector et al. 1999). Diverse swards which incorporate a variety of legume and forb species may, therefore, increase herbage production, benefitting livestock performance, and may also improve soil nutrient retention and reducing leaching. Multispecies swards have been demonstrated to have dry matter yields comparable to grass-only or grass plus clover swards (Vibart et al. 2016; McCarthy et al. 2020). For instance, Vibart et al. (2016) reported mean annual dry matter yields of $11,101 \mathrm{~kg} \mathrm{ha}^{-1}$ and $12,021 \mathrm{~kg} \mathrm{ha}^{-1}$ for simple and diverse pastures respectively. Further, cows grazing on diverse swards produce greater quantities of milk than those grazing on two-species orchard grass plus white clover swards (Soder et al. 2006). Diverse swards can also reduce invasion of weeds through greater use of space and other resources (Vibart et al. 2016). This may mitigate problems previously reported in which floral resources for pollinators in sown grasslands declined over time due to invasion of pernicious weeds (Potts et al. 2009). Complex mixtures also have greater yield consistency and diverse swards can reduce the effect of seasonality of growth due to complementary growth phenology (Vibart et al. 2016; Grace et al. 2018). Grassland biodiversity increases stability of ley performance (Doring et al. 2012) and drought resistance (Tilman and Downing 1994). The benefits of sward diversity on productivity may however plateau as producer biomass has a decelerating relationship with species richness (Cardinale et al. 2011).

Diverse swards have been demonstrated to reduce nitrate leaching by reducing the $\mathrm{N}$ content of urine patches from grazing livestock. Urine patches are the main source of $\mathrm{N}$ leaching in intensive grasslands (Ryden et al. 1984), and diverse swards decrease the proportion of dietary $\mathrm{N}$ excreted via urine by increasing the proportion incorporated into milk (Woodward et al. 2012; Totty et al. 2013). Diverse grasslands are also better able to utilise soil mineral nitrogen and therefore further reduce nitrate leaching (Tilman et al. 1996). Furthermore, incorporating legumes containing condensed tannins into livestock diets, such as Lotus spp. and Hedysarum spp., can reduce methane emissions per unit dry matter intake from grazing ruminants (Waghorn et al. 2002; Ledgard et al. 2009).

\section{Considering clover in landscape development and farm support policies}

Grassland has the potential to play an increasingly beneficial role in the farming matrix as practices shift from reliance on high artificial $\mathrm{N}$ input to symbiotically fixed $\mathrm{N}$. As discussed above, benefits of grass plus clover or diverse swards with other legumes or non-legumes may be a valuable way of maintaining high productivity while also reducing nitrate leaching and GHG emissions, improving soil health, sustaining flower-visiting insects (and insects which feed on plants in other ways) and farmer income. Shifts in attitude along these lines are already found in researchers and government agencies (Andrews et al. 2007; McKenna et al. 2018b; Murphy-Bokern et al. 2017). For example, DEFRA (2018) identified the use of diverse sward mixtures and the incorporation of legumes into crop rotations as organic practices suitable for incorporating into conventional farms. Furthermore, as part of the UK government's new Sustainable Farming Incentive several new improved grassland 'standards' are being piloted which aim to improve the sustainability of improved grasslands. These include the 'improved grassland standard' (DEFRA 2021b) and the 'improved grasslands soil standard' (DEFRA 2021a), both of which include establishing grass plus clover swards and diverse swards as components of the incentivisation scheme. Existing and future schemes should be designed with benefits to flower visiting insects as an added consideration to maximise co-benefits to the farmer and environment. Such considerations may include carefully tailoring sward composition to expand the range of insect species which benefit from improved resources while simultaneously providing agronomic benefits or altering management to allow clover and other flowers to bloom. Co-benefits not only include the agronomic and environmental benefits already discussed but also societal benefits, as biodiversity conservation is itself a cultural service and has intrinsic value in its own right (Senapathi et al. 2015). Enhancing agricultural landscapes with more flowering plants which attract pollinators will also contribute to the scenic value of rural areas (Wratten et al. 2012).

The potential benefits to flowering insects from this conservation strategy may vary depending on farm and landscape context. At the local level, direct economic benefits derived from an increase in pollination services from improved resource provision may not be advantageous to pure livestock farms as these do not grow crops that need pollination. Therefore, the pollination benefits of increased use of clover may be maximised by combining with other extensification strategies, such as incorporating leys into crop rotations (DEFRA 2018; Martin et al. 2020). In the UK only approximately $10 \%$ of farms are mixed (arable and animal, DEFRA 2017), and incorporation of temporary grassland into crop rotations is generally restricted to organic farming (Power and Stout 2011). Further, incorporation of leys into crop rotations may not be economically viable unless costs of incorporation can be offset by income from livestock production or renting land for livestock (DEFRA 2018), which may prove difficult because arable and livestock farming are often geographically separated in the UK (Weis 2013). This may be overcome through the encouragement of greater collaboration between livestock farmers and 
arable farmers using leys, such as through an online information platform as suggested by DEFRA (2018). It may therefore be desirable to link support for livestock integration to the existence of clover-sown or diverse grassland swards. Nevertheless, leys, either incorporated into rotations or undersown, may still be beneficial in arable regions, as this practice was viewed favourably by farmers due to reported benefits for soil health, disease control and weed suppression (DEFRA 2018). Payments incentivising incorporation of grass and herbal leys into arable rotations are currently (as of 2021) being piloted as part of the Sustainable Farming Incentive (DEFRA 2021d).

The benefits for insects from increased use of grass plus clover swards will also be dependent on the landscape context. The modest enhancements to floral resources may be more beneficial in homogenous and florally barren landscapes and may create a larger ecological contrast, magnifying positive responses of insect populations to introduced resources (Heard et al. 2007; Scheper et al. 2015). In this respect, improvement of flora resources through establishing wildflower strips implemented in complex landscapes have been found not to improve the already high levels of biodiversity (Scheper et al. 2015). Sown grass plus clover swards in permanent or temporary grassland will also be more beneficial in homogenous landscapes by being able to partly supplement the lack of florally-diverse semi-natural habitats (Krimmer et al. 2019). Landscape context also influences community composition because pollinator species richness declines with increased landscape homogeneity (Andersson et al. 2013). Isolation of wildflower patches in calcareous grasslands decreases the abundance and richness of flowervisiting bees (Steffan-Dewenter and Tscharntke 1999). Further, the mean body size of the recorded species was positively correlated with isolation, indicating that smaller bee species may be more vulnerable to landscape fragmentation due to their shorter foraging distances (Greenleaf et al. 2007). As binary grass plus clover and diverse swards may have an increased net benefit in more homogenous or florally barren landscapes, incentivisation schemes with a regionally targeted structure may be beneficial (Senapathi et al. 2015).

\section{Discussion and conclusion}

Improving the floral resources for flower-visiting insects represents an additional potential benefit arising from greater adoption or re-adoption of grass plus clover mixes in both permanent and temporary grasslands, and on both small and large scales. Given that shifts in policies and farming practices are already underway, for example through incentivisation schemes (DEFRA 2021a, b), researchers (Andrews et al. 2007), and among farmers (e.g. in government surveys, DEFRA 2018; in popular publications, Farmers Weekly 2017; Davidson 2021), and that environmental concerns are increasing, this added benefit is relevant and important as it can add impetus to beneficial changes in grassland management. Helping flower visiting insects is a relevant and important aspect of a wider adoption of grass plus clover swards and may add further impetus to beneficial changes in grassland management.

The implementation of more diverse swards is likely to benefit a wider range of flower-visiting insects and can also provide further agronomic benefits or at least be neutral in this respect. More work needs to be done to understand how to combine the agronomic benefits with the benefits to flower-visiting insects in the provision of diverse seed mixes, such as by examining the possibility of including a wider range of forb species in grass plus forb seed mixes, including species of Apiaceae, Asteraceae and Geraniaceae which are beneficial to Andrena and Lasioglossum wild bees (Nichols et al. 2019). Importantly, the composition of diverse mixes should also produce agronomic benefits for the farmer, such as via complementary functional traits, growth timings and resource use. Other ecosystem services, such as biological control, may also be enhanced through the targeted inclusion of plant species which provide resources for beneficial species while minimising benefits to pest species (Lu et al. 2014).

Management is also an important consideration for enhancing the benefits of mixed grassland to insects. Cutting and grazing intensity and frequency will affect the floral species richness and sward structural complexity (Potts et al. 2009; Woodcock et al. 2009, 2014) and the degree to which flowers are able to bloom. Woodcock et al. (2014) reported greater floral resources, pollinator abundance, and pollinator richness in response to extensive grazing and silage management in intensive UK grasslands. Treating the grassland with a single cut in May for silage or suspending grazing from June-August created a summer window allowing the complete phenological development of constituent plant species, increasing resource supply.

The use of clover should ideally be a component of wider agricultural strategies that also have environmental or wildlife benefits. Indeed, pollinating insects require resources other than nectar and pollen. Bees require nest sites, whereas Lepidoptera and some Diptera require larval food plants which are often species specific (Thomas et al. 2011; Senapathi et al. 2017). Landscape heterogeneity and connectivity are additional factors which will influence pollinator communities and interact with other conservation strategies. The relevant spatial scale will vary depending on species, with smaller bee species more vulnerable to landscape fragmentation due to smaller foraging distances (Greenleaf et al. 2007). In contrast, honey bees can forage up to $10 \mathrm{~km}$ and routinely forage $1-2 \mathrm{~km}$ from the hive (Couvillon et al. 
2014b), therefore the relevant scale will be larger than the average farm (DEFRA 2021e).

Although growing a single clover species with grass may directly benefit only a relatively small number of flowervisiting insect species, it is possible that mass flowering of clover may cause community changes in surrounding habitats through movement of honeybees and bumblebees into clover-rich grasslands from the surrounding landscape. This may have several effects. Honeybees and bumblebees from adjacent habitats may be drawn to clover-rich grasslands from adjacent habitats, reducing exploitative competition for alternative resources (Balfour et al. 2015b, 2021; GonzálezVaro and Vilà 2017; Wignall et al. 2020b). This has been demonstrated for the mass-flowering legume Hedysarum coronarium, where honeybees were less abundant in shrubland adjacent to Hedysarum crops (Montero-Castaño et al. 2016). This may indirectly benefit other insect species by reducing competitive exclusion of flower visiting insect species by more competitive honeybees and bumblebees (Wojcik et al. 2018; Balfour et al. 2021). Alternatively, mass flowering of clover may cause pollinator spillover onto adjacent habitats and increase exploitative competition, as has been demonstrated for oilseed rape (Diekötter et al. 2010). Furthermore, removal or spillover of insects from adjacent habitats may affect reproduction of other beepollinated wildflowers (Holzschuh et al. 2011). Determining the changes in pollinator communities in adjacent habitats in response to flowering of clover is an important avenue of future research especially during seasons when competition for floral resources is most intense, such as in July and August in parts of Britain, when more flower-visiting insects are active (75\%; Balfour et al. 2018; Wignall et al. 2020a, b).

Finally, a key topic not specifically considered in this article which is of fundamental importance but which is often overlooked is that of farmer attitudes and behaviour. After all, the farmers manage the land and plant the seeds. Marr and Howley (2019) identified five orientations which influence the implementation of pro-environmental practices by individual farmers: environmental (e.g. biodiversity, climate change), lifestyle (e.g. recreation), production, business and farm health (sustainability). Arguments and incentives encouraging wider adoption of grass plus clover swards or diverse swards may be through one or several of Marr and Howley's (2019) orientations. Further, these orientations may be a useful framework to understand and address potential barriers to wider adoption of grass plus clover or diverse swards. Determining this is important as mismatches in the perceived costs and benefits of agricultural practices occur between scientists and farmers, with scientists sometimes highlighting ecological processes or global benefits rather than the economic benefits to individual farms and farmers (Kleijn et al. 2019). DEFRA (2018) highlighted several barriers which may hinder adoption of sustainable practices. These include farm type (as discussed above), lack of accessible information and support, complexities arising from compliance with regulations, and initial investment. Understanding these motivations is essential as farmers ultimately make most of the management decisions for 70-75\% of UK land area in the UK (DEFRA 2019), including many that make significant changes to the environment (Foley et al. 2011).

Acknowledgements We thank Nicholas Balfour, Norman Carreck and Veronica Wignall for providing comments and advice that helped improve the manuscript. Key funding for this research was provided by the Elizabeth Creek Charitable Trust who are funding CH's PhD.

Funding Support for this research was provided by the Elizabeth Creek Charitable Trust which funds CH's PhD.

Availability of data and material Not applicable.

Code availability Not applicable.

\section{Declarations}

Competing interest The authors declare that they have no known competing financial interests or personal relationships that could have appeared to influence the work reported in this paper.

Ethical approval Not applicable.

Consent to participate Not applicable.

Consent for publication The author transfers publication rights to Springer.

Open Access This article is licensed under a Creative Commons Attribution 4.0 International License, which permits use, sharing, adaptation, distribution and reproduction in any medium or format, as long as you give appropriate credit to the original author(s) and the source, provide a link to the Creative Commons licence, and indicate if changes were made. The images or other third party material in this article are included in the article's Creative Commons licence, unless indicated otherwise in a credit line to the material. If material is not included in the article's Creative Commons licence and your intended use is not permitted by statutory regulation or exceeds the permitted use, you will need to obtain permission directly from the copyright holder. To view a copy of this licence, visit http://creativecommons.org/licenses/by/4.0/.

\section{References}

Addiscott TM (1996) Fertilizers and nitrate leaching. In: Agricultural chemicals and the environment. Issues in environmental science technology, vol 5, pp 1-26

AHDB (2018) Improving pasture for better returns. https://ahdb.org. uk/knowledge-library/improving-pasture-for-better-returns. Accessed 23 May 2020

Aizen MA, Garibaldi LA, Cunningham SA, Klein AM (2008) Longterm global trends in crop yield and production reveal no current pollination shortage but increasing pollinator dependency. Curr Biol 18:1572-1575. https://doi.org/10.1016/j.cub.2008.08.066 
Alford DV (1975) Bumblebees. Davis-Poynter Ltd, London

Andersson GKS, Birkhofer K, Rundlöf M, Smith HG (2013) Landscape heterogeneity and farming practice alter the species composition and taxonomic breadth of pollinator communities. Basic Appl Ecol 14:540-546. https://doi.org/10.1016/j.baae.2013.08.003

Andrews M, Scholefield D, Abberton MT et al (2007) Use of white clover as an alternative to nitrogen fertiliser for dairy pastures in nitrate vulnerable zones in the UK: productivity, environmental impact and economic considerations. Ann Appl Biol 151:11-23. https://doi.org/10.1111/j.1744-7348.2007.00137.x

Armstrong RD, McCosker K, Johnson SB et al (1999) Legume and opportunity cropping systems in central Queensland. 1. Legume growth, nitrogen fixation, and water use. Aust J Agric Res 50:909-924

Bailey A, Leigh S, Zhang M (2015) Report on farmers' attitudes towards on-site ecosystem services. EU Liberation Deliverable 5.1 Report. http://www.fp7liberation.eu/home/publications. Accessed 10 Aug 2020

Balfour NJ, Fensome KA, Samuelson EEW, Ratnieks FLW (2015a) Following the dance: ground survey of flowers and flower-visiting insects in a summer foraging hotspot identified via honey bee waggle dance decoding. Agric Ecosyst Environ 213:265-271. https://doi.org/10.1016/j.agee.2015.08.007

Balfour NJ, Gandy S, Ratnieks FLW (2015b) Exploitative competition alters bee foraging and flower choice. Behav Ecol Sociobiol 69:1731-1738. https://doi.org/10.1007/s00265-015-1985-y

Balfour NJ, Ollerton J, Castellanos MC, Ratnieks FLW (2018) British phenological records indicate high diversity and extinction rates among late-summer-flying pollinators. Biol Conserv 222:278283. https://doi.org/10.1016/j.biocon.2018.04.028

Balfour NJ, Shackleton K, Arscott NA et al (2021) Energetic efficiency of foraging mediates bee niche partitioning. Ecology. https://doi. org/10.1002/ecy.3285

Barneze AS, Whitaker J, McNamara NP, Ostle NJ (2020) Legumes increase grassland productivity with no effect on nitrous oxide emissions. Plant Soil 446:163-177. https://doi.org/10.1007/ s11104-019-04338-w

Barr CJ, Bunce RGH, Gillespie MK, Howard DC, Maskell LC, Norton LR, et al (2014a) Countryside Survey 1998 vegetation plot data. In: NERC Environmental Information Data Centre. https://doi. org/10.5285/07896bb2-7078-468c-b56d-fb8b41d47065

Barr CJ, Bunce RGH, Gillespie MK et al (2014b) Countryside Survey 1990 vegetation plot data. In: NERC Environmental Information Data Centre. https://doi.org/10.5285/26e79792-5ffc-4116-9ac7$72193 \mathrm{dd} 7 \mathrm{f} 191$

Barr CJ, Bunce RGH, Smart SM, Whittaker HA (2014c) Countryside Survey 1978 vegetation plot data. In: NERC Environmental Information Data Centre. https://doi.org/10.5285/67bbfabbd981-4ced-b7e7-225205de9c96

Baude M, Kunin WE, Boatman ND et al (2016) Historical nectar assessment reveals the fall and rise of floral resources in Britain. Nature 530:85-88. https://doi.org/10.1038/nature16532

Becher MA, Osborne JL, Thorbek P et al (2013) Towards a systems approach for understanding honeybee decline: a stocktaking and synthesis of existing models. J Appl Ecol 50:868-880. https:// doi.org/10.1111/1365-2664.12112

Berntsen J, Grant R, Olesen JE et al (2006) Nitrogen cycling in organic farming systems with rotational grass-clover and arable crops. Soil Use Manag 22:197-208. https://doi.org/10.1111/j.14752743.2005.00016.x

Black AD, Laidlaw AS, Moot DJ, O'Kiely P (2009) Comparative growth and management of white and red clovers. Irish J Agric Food Res 48:149-166

Blackstock TH, Rimes CA, Stevens DP et al (1999) The extent of seminatural grassland communities in lowland England and Wales: a review of conservation surveys 1978-96. Grass Forage Sci 54:1-18. https://doi.org/10.1046/j.1365-2494.1999.00157.x

Branquart E, Hemptinne J-L (2000) Selectivity in the exploitation of floral resources by hoverflies (Diptera: Syrphinae). Ecography 23:732-742. https://doi.org/10.1111/j.1600-0587.2000.tb00316.x

Brassley P (2000) Output and technical change in twentieth-century British agriculture. Secur Stud 48:60

Brock JL, Caradus JR, Hay MJM (1989) Fifty years of white clover research in New Zealand. Proc New Zeal Grassl Assoc 50:25-39. https://doi.org/10.33584/jnzg.1989.50.1868

Brown R, Döring T, Storkey J et al (2012) Legume based plant mixtures for delivery of ecosystem services: pollinators. Agriculture and the environment IX, valuing ecosystems: policy, economic and management interactions, pp 156-162

Brozyna MA, Petersen SO, Chirinda N, Olesen JE (2013) Effects of grass-clover management and cover crops on nitrogen cycling and nitrous oxide emissions in a stockless organic crop rotation. Agric Ecosyst Environ 181:115-126. https://doi.org/10.1016/j. agee.2013.09.013

Bunce RGH, Carey PD, Maskell LC et al (2014) Countryside Survey 2007 vegetation plot data. NERC Environmental Information Data Centre. https://doi.org/10.5285/57f97915-8ff1-473b$8 \mathrm{c} 77-2564 \mathrm{cbd} 747 \mathrm{bc}$

Cardinale BJ, Matulich KL, Hooper DU et al (2011) The functional role of producer diversity in ecosystems. Am J Bot 98:572592. https://doi.org/10.3732/ajb.1000364

Carreck N, Little DJ (1993) Nectar sources for honey bees and the movement of honey bee colonies for crop pollination and honey production in England. Bee World 74:160-175. https:// doi.org/10.1080/0005772X.1993.11099182

Carreck N, Williams I (1998) The economic value of bees in the UK. Bee World 79:115-123. https://doi.org/10.1080/00057 72X.1998.11099393

Carreck NL, Williams IH, Little DJ (1997) The movement of honey bee colonies for crop pollination and honey production by beekeepers in Great Britain. Bee World 78:67-77. https://doi.org/ 10.1080/0005772X.1997.11099337

Carvell C, Roy DB, Smart SM et al (2006) Declines in forage availability for bumblebees at a national scale. Biol Conserv 132:481-489. https://doi.org/10.1016/j.biocon.2006.05.008

Carvell C, Meek WR, Pywell RF et al (2007) Comparing the efficacy of agri-environment schemes to enhance bumble bee abundance and diversity on arable field margins. J Appl Ecol 44:29-40. https://doi.org/10.1111/j.1365-2664.2006.01249.x

Chamberlain DE, Fuller RJ, Bunce RGH et al (2000) Changes in the abundance of farmland birds in relation to the timing of agricultural intensification in England and Wales. J Appl Ecol 37:771-788. https://doi.org/10.1046/j.1365-2664.2000. 00548.x

Chapman DF, Lee JM, Rossi L et al (2017) White clover: the forgotten component of high-producing pastures? Anim Prod Sci 57:1269-1276. https://doi.org/10.1071/AN16453

Chorley GPH (1981) The Agricultural Revolution in Northern Europe, 1750-1880: nitrogen, legumes, and crop productivity. Econ Hist Rev 34:71-93. https://doi.org/10.1111/j.1468-0289.1981.tb020 07.x

Clark DA, Harris SL (1995) White clover or nitrogen fertiliser for dairying? NZGA Res Pract Ser 6:107-114. https://doi.org/10. 1071/AN18577

Couvillon MJ, Fensome KA, Quah SKL, Schürch R (2014a) Summertime blues: August foraging leaves honey bees empty-handed. Commun Integr Biol. https://doi.org/10.4161/cib.28821

Couvillon MJ, Schürch R, Ratnieks FLW (2014b) Waggle dance distances as integrative indicators of seasonal foraging challenges. PLoS ONE 9:1-7. https://doi.org/10.1371/journal.pone.0093495 
Crane E (1976) Honey. A comprehensive survey. Heinemann Publishing, Portsmouth

Curll ML, Wilkins RJ (1983) The comparative effects of defoliation, treading and excreta on a Lolium perenne-Trifolium repens pasture grazed by sheep. J Agric Sci 100:451-460

Davidson G (2021) Could clover be the 'holy grail' of arable farming? The Scottish Farmer. https://www.thescottishfarmer.co.uk/ news/19328154.clover-holy-grail-arable-farming/. Accessed 7 Oct 2021

de Haas BR, Hoekstra NJ, van der Schoot JR et al (2019) Combining agro-ecological functions in grass-clover mixtures. AIMS Agric Food 4:547-567. https://doi.org/10.3934/agrfood.2019.3.547

Deans A (1957) Survey of British honey sources. Bee Res Assoc. https://doi.org/10.1080/0005772x.1957.11094999

Decourtye A, Mader E, Desneux N (2010) Landscape enhancement of floral resources for honey bees in agro-ecosystems. Apidologie 41:264-277. https://doi.org/10.1051/apido/2010024

DEFRA (2017) Greenhouse gas mitigation practices-England farm practices survey 2017. In: Electron. dataset. https://www.gov. uk/government/statistics/farm-practices-survey-february-2017greenhouse-gas-mitigation-practices. Accessed 23 May 2020

DEFRA (2018) Reviewing the opportunities, barriers and constraints for organic management techniques to improve sustainability of conventional farming. http://sciencesearch.defra.gov.uk/Default. asp $\mathrm{x}$ Menu $=$ Menu $\&$ Module $=$ More $\&$ Location $=$ None $\&$ Compl eted $=0 \&$ ProjectID $=20252$. Accessed 7 Oct 2021

DEFRA (2019) Agriculture in the United Kingdom 2019. In: Electron. dataset. https://www.gov.uk/government/statistical-data-sets/ agriculture-in-the-united-kingdom. Accessed 19 Nov 2020

DEFRA (2020a) Farm Practices Survey. In: Electron. dataset. https:// www.gov.uk/government/statistics/farm-practices-survey-febru ary-2020-greenhouse-gas-mitigation-practices. Accessed 2 Mar 2020

DEFRA (2020b) Farming is changing. https://www.gov.uk/gover nment/publications/future-farming-changes-to-farming-ineng land. Accessed 7 Oct 2021

DEFRA (2021a) Improved grassland soils standard of the Sustainable Farming Incentive pilot. https://www.gov.uk/guidance/improvedgrassland-soils-standard. Accessed 7 Oct 2021

DEFRA (2021b) Improved grassland standard of the Sustainable Farming Incentive pilot. https://www.gov.uk/guidance/improved-grass land-standard. Accessed 7 Oct 2021

DEFRA (2021c) Nitrate vulnerable zones. https://www.gov.uk/gover nment/collections/nitrate-vulnerable-zones. Accessed 4 Oct 2021

DEFRA (2021d) Arable and horticultural soils standard of the Sustainable Farming Incentive pilot. https:/www.gov.uk/guidance/ arable-and-horticultural-soils-standard. Accessed 7 Oct 2021

DEFRA (2021e) Structure of the agricultural industry in England and the UK at June. In: Electron. dataset. https://www.gov.uk/gover nment/statistical-data-sets/structure-of-the-agricultural-industryin-england-and-the-uk-at-june. Accessed 7 Apr 2021

Diekötter T, Kadoya T, Peter F et al (2010) Oilseed rape crops distort plant-pollinator interactions. J Appl Ecol 47:209-214. https:// doi.org/10.1111/j.1365-2664.2009.01759.x

Doel JM (2013) Accumulation and recovery of nitrogen in mixed farming systems using legumes and other fertility-building crops

Doring T, Sorkey J, Baddeley J et al (2012) Legume-based plant mixtures for delivery of multiple ecosystem services: an overview of benefits. Agriculture and the environment IX, valuing ecosystems: policy, economic and management interactions, pp $150-155$

Doyle CJ, Morrison J, Brockman JS et al (1984) Economic aspects of using legumes. Forage Legum, pp 152-165

Ellis JD, Evans JD, Pettis J (2010) Colony losses, managed colony population decline, and Colony Collapse Disorder in the United
States. J Apic Res 49:134-136. https://doi.org/10.3896/IBRA.1. 49.1.30

Environmental Audit Committee (2018) UK progress on reducing nitrate pollution. HC 656. https://publications.parliament.uk/ $\mathrm{pa} / \mathrm{cm} 201719 / \mathrm{cmselect} / \mathrm{cmenvaud} / 656 / 656$.pdf. Accessed 29 Oct 2020

Eriksen J (2001) Nitrate leaching and growth of cereal crops following cultivation of contrasting temporary grasslands. J Agric Sci 136:271-281. https://doi.org/10.1017/S0021859601008802

Eurostat (2002) Handbook for EU agricultural price statistics. https:// ec.europa.eu/eurostat/web/products-manuals-and-guidelines/-/ KS-BH-02-003. Accessed 7 Nov 2021

Evans PS (1977) Comparative root morphology of some pasture grasses and clovers. New Zeal J Agric Res 20:331-335. https:// doi.org/10.1080/00288233.1977.10427343

FAS (2019) Fertiliser recommendations for grassland (TN726). https:// www.fas.scot/publication/technical-note-tn726-fertiliserrecom mendations-for-grassland/. Accessed 16 Mar 2021

Farmers Weekly (2017) Growing clover helps sheep farmer cut feed costs. Farmers weekly. https://www.fwi.co.uk/livestock/grass land-management/growing-annual-clover-cuts-sheep-feed-costs. Accessed 7 Nov 2021

Firbank LG (2005) Striking a new balance between agricultural production and biodiversity. Ann Appl Biol 146:163-175. https:// doi.org/10.1111/j.1744-7348.2005.040078.x

Foley JA, Ramankutty N, Brauman KA et al (2011) Solutions for a cultivated planet. Nature 478:337-342. https://doi.org/10.1038/ nature 10452

Frame J (1987) The role of white clover in United Kingdom pastures. Outlook Agric 16:28-34. https://doi.org/10.1177/0030727090 01900110

Frame J (1990) The role of red clover in United Kingdom pastures. Outlook Agric 19:49-55. https://doi.org/10.1177/0030727090 01900110

Frame J, Newbould P (1986) Agronomy of white clover. Adv Agron 40:1-88. https://doi.org/10.1016/S0065-2113(08)60280-1

Frame J (2005) Forage legumes for temperate grasslands. Science Publishers

Frankow-Lindberg B (2017) Red clover in cropping systems. In: Legumes in cropping systems. CABI Publishing, Wallingford, pp $157-168$

Fraser MD, Speijers MHM, Theobald VJ et al (2004) Production performance and meat quality of grazing lambs finished on red clover, lucerne or perennial ryegrass swards. Grass Forage Sci 59:345-356. https://doi.org/10.1111/j.1365-2494.2004.00436.x

Fussell G (1964) The grasses and grassland cultivation of Britain. Grass Forage Sci 19:212-217. https://doi.org/10.1111/j.13652494.1964.tb01140.x

Fussell M (1992) Diurnal patterns of bee activity, flowering, and nectar reward per flower in tetraploid red clover. New Zeal J Agric Res 35:151-156. https://doi.org/10.1080/00288233.1992.10417712

Fussell M, Corbet SA (1991) Forage for bumble bees and honey bees in farmland: a case study. J Apic Res 30:87-97. https://doi.org/ 10.1080/00218839.1991.11101239

Garbuzov M, Ratnieks FLW (2014) Quantifying variation among garden plants in attractiveness to bees and other flower-visiting insects. Funct Ecol 28:364-374. https://doi.org/10.1111/13652435.12178

Giddey S, Badwal SPS, Munnings C, Dolan M (2017) Ammonia as a renewable energy transportation media. ACS Sustain Chem Eng 5:10231-10239. https://doi.org/10.1021/acssuschemeng.7b02219

Gilbert F (1981) Foraging ecology of hoverflies: morphology of the mouthparts in relation to feeding on nectar and pollen in some common urban species. Ecol Entomol 6:245-262. https://doi.org/ 10.1111/j.1365-2311.1981.tb00612.x 
González-Varo JP, Vilà M (2017) Spillover of managed honeybees from mass-flowering crops into natural habitats. Biol Conserv 212:376-382. https://doi.org/10.1016/j.biocon.2017.06.018

Goulson D, Hanley ME (2004) Distribution and forage use of exotic bumblebees in South Island, New Zealand. N Z J Ecol 28:225-232

Goulson D, Hanley ME, Darvill B et al (2005) Causes of rarity in bumblebees. Biol Conserv 122:1-8. https://doi.org/10.1016/j. biocon.2004.06.017

Goulson D, Nicholls E, Botías C, Rotheray EL (2015) Bee declines driven by combined Stress from parasites, pesticides, and lack of flowers. Science. https://doi.org/10.1126/science.1255957

Grace C, Boland TM, Sheridan H et al (2018) The effect of increasing pasture species on herbage production, chemical composition and utilization under intensive sheep grazing. Grass Forage Sci 73:1-13. https://doi.org/10.1111/gfs.12379

Greenleaf SS, Williams NM, Winfree R, Kremen C (2007) Bee foraging ranges and their relationship to body size. Oecologia 153:589-596. https://doi.org/10.1007/s00442-007-0752-9

Gregory PJ (2006) Roots, rhizosphere and soil: the route to a better understanding of soil science? Eur J Soil Sci 57:2-12. https:// doi.org/10.1111/j.1365-2389.2005.00778.x

Hanley ME, Franco M, Pichon S et al (2008) Breeding system, pollinator choice and variation in pollen quality in British herbaceous plants. Funct Ecol 22:592-598. https://doi.org/10.1111/j.13652435.2008.01415.x

Hardman CJ (2016) Delivering biodiversity and pollination services on farmland : a comparison of three wildlife-friendly farming schemes

Hatch DJ, Goodlass G, Joynes A, Shepherd MA (2007) The effect of cutting, mulching and applications of farmyard manure on nitrogen fixation in a red clover/grass sward. Bioresour Technol 98:3243-3248. https://doi.org/10.1016/j.biortech.2006.07.017

Haynes RJ (1980) Competitive aspects of the grass-legume association. Adv Agron 33:227-256

Heard MS, Carvell C, Carreck NL et al (2007) Landscape context not patch size determines bumble-bee density on flower mixtures sown for agri-environment schemes. Biol Lett 3:638-641. https:// doi.org/10.1098/rsbl.2007.0425

Hector A, Schmid B, Beierkuhnlein C et al (1999) Plant diversity and productivity experiments in European grasslands. Science 286:1123-1127. https://doi.org/10.1126/science.286.5442.1123

Høgh-Jensen H, Schjoerring JK (1997) Residual nitrogen effect of clover-ryegrass swards on yield and $\mathrm{N}$ uptake of a subsequent winter wheat crop as studied by use of $15 \mathrm{~N}$ methodology and mathematical modelling. Eur J Agron 6:235-243. https://doi.org/ 10.1016/S1161-0301(96)02050-3

Høgh-Jensen H, Loges R, Jørgensen FV et al (2004) An empirical model for quantification of symbiotic nitrogen fixation in grassclover mixtures. Agric Syst 82:181-194. https://doi.org/10. 1016/j.agsy.2003.12.003

Holzschuh A, Dormann CF, Tscharntke T, Steffan-Dewenter I (2011) Expansion of mass-flowering crops leads to transient pollinator dilution and reduced wild plant pollination. Proc R Soc B Biol Sci 278:3444-3451. https://doi.org/10.1098/rspb.2011.0268

Horn J, Becher MA, Johst K et al (2019) Honeybee colony performance affected by crop diversity and farmland structure : a modelling framework. bioRxiv 18:64. https://doi.org/10.1101/2019.12.17. 880054

Humphreys J, Phelan P, Li D et al (2017) White clover supported pasture systems in north-west Europe. In: Legumes in cropping systems. CABI Publishing, Wallingford, pp 139-153

IPCC (2006) 2006 IPCC Guidelines for national greenhouse gas inventories, national greenhouse gas inventories programme. https:// www.ipccnggip.iges.or.jp/public/2006gl/index.html. Accessed 7 Nov 2021
IPCC (2014) Climate change 2014: Synthesis report. https://www.ipcc. ch/report/ar5/syr/. Accessed 17 Nov 2020

Jarvis SC (1993) Nitrogen cycling and losses from dairy farms. Soil Use Manag 9:99-104. https://doi.org/10.1111/j.1475-2743.1993. tb00937.x

Jauker F, Bondarenko B, Becker HC, Steffan-Dewenter I (2012) Pollination efficiency of wild bees and hoverflies provided to oilseed rape. Agric for Entomol 14:81-87. https://doi.org/10.1111/j. 1461-9563.2011.00541.x

Johnson R, Thompson (1996) Effect of pasture species on milk yield and milk composition. Proc New Zeal Grassl Assoc 57:151-155

Jørgensen FV, Jensen ES, Schjoerring JK (1999) Dinitrogen fixation in white clover grown in pure stand and mixture with ryegrass estimated by the immobilized $15 \mathrm{~N}$ isotope dilution method. Plant Soil 208:293-305. https://doi.org/10.1023/A:1004533430467

Kitsikopoulos H (2004) Convertible husbandry vs regular common fields: a model on the relative efficiency of Medieval field systems. J Econ Hist 64:462-499. https://doi.org/10.1017/s0022 050704002761

Kjærgaard T (2003) A plant that changed the world: the rise and fall of clover 1000-2000. Landsc Res 28:41-49. https://doi.org/10. 1080/01426390306531

Kleijn D, Raemakers I (2008) A retrospective analysis of pollen host plant use by stable and declining bumble bee species. Ecology 89:1811-1823. https://doi.org/10.1890/07-1275.1

Kleijn D, Bommarco R, Fijen TPM et al (2019) Ecological intensification: bridging the gap between science and practice. Trends Ecol Evol 34:154-166. https://doi.org/10.1016/j.tree.2018.11.002

Klein AM, Vaissière BE, Cane JH et al (2007) Importance of pollinators in changing landscapes for world crops. Proc R Soc B Biol Sci 274:303-313. https://doi.org/10.1098/rspb.2006.3721

Knowles IM, Fraser TJ, Daly MJ (2003) White clover: loss in drought and subsequent recovery. Legum Dryl Pastures Grassl Res Pract Ser 11:37-41

Koehler-Cole K, Brandle JR, Francis CA et al (2016) Clover green manure productivity and weed supression in an organic grain rotation. Renew Agric Food Syst 32:1-10

Krimmer E, Martin EA, Krauss J et al (2019) Size, age and surrounding semi-natural habitats modulate the effectiveness of flower-rich agri-environment schemes to promote pollinator visitation in crop fields. Agric Ecosyst Environ 284:1-8. https://doi.org/10. 1016/j.agee.2019.106590

Larson JL, Kesheimer AJ, Potter DA (2014) Pollinator assemblages on dandelions and white clover in urban and suburban lawns. J Insect Conserv 18:863-873. https://doi.org/10.1007/ s10841-014-9694-9

Ledgard SF (1991) Transfer of fixed nitrogen from white clover to associated grasses in swards grazed by dairy cows, estimated using 15N methods. Plant Soil 131:215-223. https://doi.org/ 10.1007/BF00009451

Ledgard SF, Sprosen MS, Penno JW, Rajendram GS (2001) Nitrogen fixation by white clover in pastures grazed by dairy cows: Temporal variation and effects of nitrogen fertilization. Plant Soil 229:177-187. https://doi.org/10.1023/A:1004833804002

Ledgard SF, Schils R, Eriksen J, Luo J (2009) Environmental impacts of grazed clover/grass pastures. Irish J Agric Food Res 48:209226. https://doi.org/10.1097/EDE.0b013e3181

Levy S (2011) The pollinator crisis: what's best for bees. Nature 479:164-165. https://doi.org/10.1038/479164a

Littlewood NA, Stewart AJA, Woodcock BA (2012) Science into practice-how can fundamental science contribute to better management of grasslands for invertebrates? Insect Conserv Divers 5:1-8. https://doi.org/10.1111/j.1752-4598.2011. 00174.x

Liu X, Elgowainy A, Wang M (2020) Life cycle energy use and greenhouse gas emissions of ammonia production from renewable 
resources and industrial by-products. Green Chem 22:57515761. https://doi.org/10.1039/d0gc02301a

Lu ZX, Zhu PY, Gurr GM et al (2014) Mechanisms for flowering plants to benefit arthropod natural enemies of insect pests: Prospects for enhanced use in agriculture. Insect Sci 21:1-12. https://doi. org/10.1111/1744-7917.12000

Luo J, de Klein CAM, Ledgard SF, Saggar S (2010) Management options to reduce nitrous oxide emissions from intensively grazed pastures: a review. Agric Ecosyst Environ 136:282-291. https:// doi.org/10.1016/j.agee.2009.12.003

Lüscher A, Finn JA, Connolly J et al (2008) Benefits of sward diversity for agricultural grasslands. Biodiversity 9:29-32. https://doi.org/ 10.1080/14888386.2008.9712877

Lüscher A, Mueller-Harvey I, Soussana JF et al (2014) Potential of legume-based grassland-livestock systems in Europe: a review. Grass Forage Sci 69:206-228. https://doi.org/10.1111/gfs.12124

Malone L, Aulsford J, Howlett B et al (2010) Observations on bee species visiting white clover in New Zealand pastures. J Apic Res 49:284-286. https://doi.org/10.3896/ibra.1.49.3.09

Marr EJ, Howley P (2019) The accidental environmentalists: factors affecting farmers' adoption of pro-environmental activities in England and Ontario. J Rural Stud 68:100-111. https://doi.org/ 10.1016/j.jrurstud.2019.01.013

Martin G, Durand JL, Duru M et al (2020) Role of ley pastures in tomorrow's cropping systems. A Review Agron Sustain Dev 40:1-25. https://doi.org/10.1007/s13593-020-00620-9

Maskell LC, Smart SM, Bullock JM et al (2010) Nitrogen deposition causes widespread loss of species richness in British habitats. Glob Chang Biol 16:671-679. https://doi.org/10.1111/j.13652486.2009.02022.x

McCarthy KM, McAloon CG, Lynch MB et al (2020) Herb species inclusion in grazing swards for dairy cows-a systematic review and meta-analysis. J Dairy Sci 103:1416-1430. https://doi.org/ 10.3168/jds.2019-17078

McKenna P, Cannon N, Conway J et al (2018a) Red clover (Trifolium pratense) in conservation agriculture: a compelling case for increased adoption. Int J Agric Sustain 16:342-366. https:// doi.org/10.1080/14735903.2018.1498442

McKenna P, Cannon N, Conway J, Dooley J (2018b) The use of red clover (Trifolium pratense) in soil fertility-building: a review. Field Crop Res 221:38-49. https://doi.org/10.1016/j.fcr.2018.02.006

Mela T (2003) Red clover grown in a mixture with grasses: yield, persistence and dynamics of quality characteristics. Agric Food Sci Finl 12:195-212

Mitchell BR (1988) British historical statistics. Cambridge University Press, Cambridge

Monaghan RM, Hedley MJ, Di HJ et al (2007) Nutrient management in New Zealand pastures-recent developments and future issues. New Zeal J Agric Res 50:181-201. https://doi.org/10.1080/ 00288230709510290

Montero-Castaño A, Ortiz-Sánchez FJ, Vilà M (2016) Mass flowering crops in a patchy agricultural landscape can reduce bee abundance in adjacent shrublands. Agric Ecosyst Environ 223:22-30. https://doi.org/10.1016/j.agee.2016.02.019

Murphy-Bokern D, Stoddard FL, Watson CA (2017) Legumes in cropping systems. CABI Publishing, Boston

Naug D (2009) Nutritional stress due to habitat loss may explain recent honeybee colony collapses. Biol Conserv 142:2369-2372. https://doi.org/10.1016/j.biocon.2009.04.007

Neumann P, Carreck NL (2010) Honey bee colony losses. J Apic Res 49:1-6. https://doi.org/10.3896/IBRA.1.49.1.01

Nichols RN, Goulson D, Holland JM (2019) The best wildflowers for wild bees. J Insect Conserv 23:819-830. https://doi.org/10.1007/ s10841-019-00180-8

Nyfeler D, Huguenin-Elie O, Suter M et al (2009) Strong mixture effects among four species in fertilized agricultural grassland led to persistent and consistent transgressive overyielding. J Appl Ecol 46:683-691. https://doi.org/10.1111/j.1365-2664.2007.0

Nyfeler D, Huguenin-Elie O, Suter M et al (2011) Grass-legume mixtures can yield more nitrogen than legume pure stands due to mutual stimulation of nitrogen uptake from symbiotic and nonsymbiotic sources. Agric Ecosyst Environ 140:155-163. https:// doi.org/10.1016/j.agee.2010.11.022

Oberson A, Frossard E, Bühlmann C et al (2013) Nitrogen fixation and transfer in grass-clover leys under organic and conventional cropping systems. Plant Soil 371:237-255. https://doi.org/10.1007/ s11104-013-1666-4

Ollerton J, Winfree R, Tarrant S (2011) How many flowering plants are pollinated by animals? Oikos 120:321-326. https://doi.org/ 10.1111/j.1600-0706.2010.18644.x

Ollerton J, Erenler H, Edwards M, Crockett R (2014) Extictions of aculeate pollinators in Britain and the role of large scale agricultural changes. Science 346:1360-1362. https://doi.org/10.1126/ science. 1257259

Orford KA, Murray PJ, Vaughan IP, Memmott J (2016) Modest enhancements to conventional grassland diversity improve the provision of pollination services. J Appl Ecol 53:906-915. https://doi.org/10.1111/1365-2664.12608

Otis GW (2007) Comments about colony collapse disorder. Am Bee J 147:1033-1035

Peoples MB, Baldock JA (2001) Nitrogen dynamics of pastures: nitrogen fixation inputs, the impact of legumes on soil nitrogen fertility, and the contributions of fixed nitrogen to Australian farming systems. Aust J Exp Agric 41:327-346. https://doi.org/10.1071/ EA99139

Peyraud JL, Le Gall A, Lüscher A (2009) Potential food production from forage legume-based-systems in Europe: an overview. Irish J Agric Food Res 48:115-135

Potts SG, Vulliamy B, Dafni A et al (2003) Linking bees and flowers: how do floral communities structure pollinator communities? Ecology 84:2628-2642. https://doi.org/10.1890/02-0136

Potts SG, Woodcock BA, Roberts SPM et al (2009) Enhancing pollinator biodiversity in intensive grasslands. J Appl Ecol 46:369-379. https://doi.org/10.1111/j.1365-2664.2009.01609.x

Potts SG, Biesmeijer JC, Kremen C et al (2010) Global pollinator declines: trends, impacts and drivers. Trends Ecol Evol 25:345353. https://doi.org/10.1016/j.tree.2010.01.007

Power EF, Stout JC (2011) Organic dairy farming: Impacts on insectflower interaction networks and pollination. J Appl Ecol 48:561569. https://doi.org/10.1111/j.1365-2664.2010.01949.x

Ranta E, Lundberg H (1980) Resource partitioning in bumblebees: the significance of differences in proboscis length. Oikos 35:298 302. https://doi.org/10.2307/3544643

Rao S, Stephen WP (2010) Abundance and diversity of native bumble bees associated with agricultural crops: the Willamette valley experience. Psyche (stuttg). https://doi.org/10.1155/2010/354072

Ratcliffe DA (1984) Post-medieval and recent changes in british vegetation: the culmination of human influence. New Phytol 98:73100. https://doi.org/10.1111/j.1469-8137.1984.tb06099.x

Requier F, Odoux JF, Henry M, Bretagnolle V (2017) The carry-over effects of pollen shortage decrease the survival of honeybee colonies in farmlands. J Appl Ecol 54:1161-1170. https://doi.org/10. $1111 / 1365-2664.12836$

Rochon JJ, Doyle CJ, Greef JM et al (2004) Grazing legumes in Europe: a review of their status, management, benefits, research needs and future prospects. Grass Forage Sci 59:197-214. https:// doi.org/10.1111/j.1365-2494.2004.00423.x

Roulston TH, Goodell K (2011) The role of resources and risks in regulating wild bee populations. Annu Rev Entomol 56:293-312. https://doi.org/10.1146/annurev-ento-120709-144802

Rundlöf M, Persson AS, Smith HG, Bommarco R (2014) Late-season mass-flowering red clover increases bumble bee queen and male 
densities. Biol Conserv 172:138-145. https://doi.org/10.1016/j. biocon.2014.02.027

Ryden JC (1983) Denitrification loss from a grassland soil in the field receiving different rates of nitrogen as ammonium nitrate. J Soil Sci 34:355-365. https://doi.org/10.1111/j.1365-2389.1983.tb010 41. $\mathrm{x}$

Ryden JC, Ball PR, Garwood EA (1984) Nitrogen cycle: nitrate leaching from grassland. Nature 311:10. https://doi.org/10.1038/31101 $0 \mathrm{a} 0$

Scheper J, Bommarco R, Holzschuh A et al (2015) Local and landscape-level floral resources explain effects of wildflower strips on wild bees across four European countries. J Appl Ecol 52:11651175. https://doi.org/10.1111/1365-2664.12479

Scholefield D, Oenema O (1997) Nutrient cycling within temperate agricultural grasslands. In: Proceedings of the 1999 18th international grassland congress. CFC/CSA/CSAS

Scholefield D, Tyson K, Armstrong A et al (1993) Nitrate leaching from grazed grassland lysimeters: effects of fertilizer input, field drainage, age of sward and patterns of weather. J Soil Sci 44:601-613. https://doi.org/10.1111/j.1365-2389.1993.tb02325.x

Senapathi D, Biesmeijer JC, Breeze TD et al (2015) Pollinator conservation - The difference between managing for pollination services and preserving pollinator diversity. Curr Opin Insect Sci 12:93-101. https://doi.org/10.1016/j.cois.2015.11.002

Senapathi D, Goddard MA, Kunin WE, Baldock KCR (2017) Landscape impacts on pollinator communities in temperate systems: evidence and knowledge gaps. Funct Ecol 31:26-37. https://doi. org/10.1111/1365-2435.12809

Sheldrick RD, Lavender RH, Tewson VJ (1986) The effects of frequency of defoliation, date of first cut and heading date of a perennial ryegrass companion on the yield, quality and persistence of diploid and tetraploid broad red clover. Grass Forage Sci 41:137-149

Smith P, Black H, Evans C, et al (2011) UK National Ecosystem Assessment. Understanding nature's value to society. Technical Report-Chapter 14: Regulating services. Unep-Wcmc 535-596

Soder KJ, Sanderson MA, Stack JL, Muller LD (2006) Intake and performance of lactating cows grazing diverse forage mixtures. J Dairy Sci 89:2158-2167. https://doi.org/10.3168/jds.S00220302(06)72286-X

Steen RWJ, Laidlaw AS (1995) The effect of fertiliser nitrogen input on the stock-carrying capacity of ryegrass/white clover swards continuously grazed by Beef Cattle. Irish J Agric Food Res 34:123-132

Steffan-Dewenter I, Tscharntke T (1999) Effects of habitat isolation on pollinator communities and seed set. Oecologia 121:432-440. https://doi.org/10.1007/s004420050949

Stinner W, Möller K, Leithold G (2008) Effects of biogas digestion of clover/grass-leys, cover crops and crop residues on nitrogen cycle and crop yield in organic stockless farming systems. Eur J Agron 29:125-134. https://doi.org/10.1016/j.eja.2008.04.006

Stoddard FL, Hovinen S, Kontturi M et al (2009) Legumes in Finnish agriculture: history, present status and future prospects. Agric Food Sci 18:191-205. https://doi.org/10.2137/145960609790059 578

Stopes C, Millington S, Woodward L (1996) Dry matter and nitrogen accumulation by three leguminous green manure species and the yield of a following wheat crop in an organic production system. Agric Ecosyst Environ 57:189-196. https://doi.org/10. 1016/0167-8809(95)01002-5

Thomas JA, Simcox DJ, Hovestadt T (2011) Evidence based conservation of butterflies. J Insect Conserv 15:241-258. https://doi.org/ 10.1007/s10841-010-9341-z

Thomson DJ, Beever DE, Haines MJ et al (1985) Yield and composition of milk from Friesian cows grazing either perennial ryegrass or white clover in early lactation. J Dairy Res 52:17-31. https:// doi.org/10.1017/S0022029900023852

Tilman D, Downing JA (1994) Biodiversity and stability in grasslands. Nature 367:363-365. https://doi.org/10.1038/367363a0

Tilman D, Wedin DA, Knops J (1996) Productivity and sustainability influenced by biodiversity in grassland ecosystems. Nature 379:718-720. https://doi.org/10.1086/419118

Timberlake T (2019) Mind the Gap : the importance of flowering phenology in pollinator conservation

Timberlake TP, Vaughan IP, Memmott J (2019) Phenology of farmland floral resources reveals seasonal gaps in nectar availability for bumblebees. J Appl Ecol 56:1585-1596. https://doi.org/10.1111/ 1365-2664.13403

Tonitto C, David MB, Drinkwater LE (2006) Replacing bare fallows with cover crops in fertilizer-intensive cropping systems: a metaanalysis of crop yield and $\mathrm{N}$ dynamics. Agric Ecosyst Environ 112:58-72. https://doi.org/10.1016/j.agee.2005.07.003

Totty VK, Greenwood SL, Bryant RH, Edwards GR (2013) Nitrogen partitioning and milk production of dairy cows grazing simple and diverse pastures. J Dairy Sci 96:141-149. https://doi.org/10. 3168/jds.2012-5504

Van Engelsdorp D, Underwood R, Caron D, Hayes J (2007) An estimate of managed colony losses in the winter of 2006-2007. Am Bee J 147:599-603

Vibart RE, Vogeler I, Dodd M, Koolaard J (2016) Simple versus diverse temperate pastures: aspects of soil-plant- animal interrelationships central to nitrogen leaching losses. Agron J 108:2174-2188. https://doi.org/10.2134/agronj2016.04.0193

Wacquant JP, Ouknider M, Jacquard P (1989) Evidence for a periodic excretion of nitrogen by roots of grass-legume associations. Plant Soil 116:57-68. https://doi.org/10.1007/BF02327257

Waghorn GC, Tavendale MH, Woodfield DR (2002) Methanogenesis from forages fed to sheep. Proc New Zeal Grassl Assoc 64:167171. https://doi.org/10.33584/jnzg.2002.64.2462

Watson CA, Atkinson D, Gosling P et al (2002) Managing soil fertility in organic farming systems. Soil Use Manag 18:239-247. https:// doi.org/10.1079/sum2002131

Watson CA, Stoddard FL (2017) Perspectives on legume production and use in European agriculture. In: Legumes in cropping systems. CABI Publishing, Wallingford, pp 1-18

Wedin DA, Tilman D (1996) Influence of nitrogen loading and species composition on the carbon balance of grasslands. Science 274:1720-1723. https://doi.org/10.1126/science.274.5293.1720

Weis T (2013) The meat of the global food crisis. J Peasant Stud 40:6585. https://doi.org/10.1080/03066150.2012.752357

Westphal C, Steffan-Dewenter I, Tscharntke T (2009) Mass flowering oilseed rape improves early colony growth but not sexual reproduction of bumblebees. J Appl Ecol 46:187-193. https://doi.org/ 10.1111/j.1365-2664.2008.01580.x

Wignall VR, Brolly M, Uthoff C et al (2020a) Exploitative competition and displacement mediated by eusocial bees: experimental evidence in a wild pollinator community. Behav Ecol Sociobiol. https://doi.org/10.1007/s00265-020-02924-y

Wignall VR, Campbell Harry I, Davies NL et al (2020b) Seasonal variation in exploitative competition between honeybees and bumblebees. Oecologia 192:351-361. https://doi.org/10.1007/ s00442-019-04576-w

Wilkins RJ, Gibb MJ, Huckle CA, Clements AJ (1994) Effect of supplementation on production by spring-calving dairy cows grazing swards of differing clover content. Grass Forage Sci 49:465-475. https://doi.org/10.1111/j.1365-2494.1994.tb02024.x

Wojcik VA, Morandin LA, Davies Adams L, Rourke KE (2018) Floral resource competition between honey bees and wild bees: is there clear evidence and can we guide management and conservation? Environ Entomol 47:822-833. https://doi.org/10.1093/ee/nvy077 
Wood S, Cowie A (2004) A review of greenhouse gas emission factors for fertiliser production. Report submitted to IEA Bioenergy Task 38, Greenhouse Gas Balances of Biomass and Bioenergy Systems. Paris, France: IEA

Wood TJ, Holland JM, Hughes WOH, Goulson D (2015) Targeted agrienvironment schemes significantly improve the population size of common farmland bumblebee species. Mol Ecol 24:1668-1680. https://doi.org/10.1111/mec.13144

Wood TJ, Holland JM, Goulson D (2017) Providing foraging resources for solitary bees on farmland: current schemes for pollinators benefit a limited suite of species. J Appl Ecol 54:323-333. https://doi.org/10.1111/1365-2664.12718

Woodcock BA, Potts SG, Tscheulin T et al (2009) Responses of invertebrate trophic level, feeding guild and body size to the management of improved grassland field margins. J Appl Ecol 46:920929. https://doi.org/10.1111/j.1365-2664.2009.01675.x

Woodcock BA, Savage J, Bullock JM et al (2014) Enhancing floral resources for pollinators in productive agricultural grasslands. Biol Conserv 171:44-51. https://doi.org/10.1016/j.biocon.2014. 01.023
Woodward SL, Waghorn GC, Bryant MA, Benton A (2012) Can diverse pasture mixtures reduce nitrogen losses? In: Proceedings of the 5th Australasian dairy science symposium, Melbourne, Australia, 13-15 November 2012. Australasian Dairy Science Symposium, Tallygaroopna, pp 463-464

Wratten SD, Gillespie M, Decourtye A et al (2012) Pollinator habitat enhancement: benefits to other ecosystem services. Agric Ecosyst Environ 159:112-122. https://doi.org/10.1016/j.agee.2012. 06.020

Zhang WF, Dou ZX, He P et al (2013) New technologies reduce greenhouse gas emissions from nitrogenous fertilizer in China. Proc Natl Acad Sci USA 110:8375-8380. https://doi.org/10.1073/ pnas. 1210447110

Publisher's Note Springer Nature remains neutral with regard to jurisdictional claims in published maps and institutional affiliations. 